\title{
Highly Optimized Tolerant (HOT) Farms in Rondônia: Productivity and Farm Size, and Implications for Environmental Licensing
}

\author{
Andrew Reid Bell $^{1}$
}

\begin{abstract}
This paper operationalizes the concept of highly optimized tolerance (HOT) for the case of smallholder agriculture in Rondônia, Brazil. It seeks to understand how characteristics of family farms shift as a function of property size, arguing that as production intensifies, properties move closer to a HOT state. In this state, resources are committed to maintaining robustness against expected disturbances, such as shifts in yields or crop prices, making property more vulnerable to other unexpected disturbances, such as shifts in input prices or availability. The shifts in production, labor, and costs that occur across scale in the Ji-Paraná River Basin in Rondônia were measured using a survey instrument on a sample of farmers in the basin. Study results show decreasing production intensity with increasing property size in the sample, coupled with decreasing contracted and family labor use intensity, as well as decreased income diversification and off-farm labor. Farms smaller than 60 ha in the sample differed markedly in production and cost structure from those that were larger. For these smaller properties, meeting the requirements of Rondônia's new environmental licensing program (LAPRO) may lead to an increase in the sale of land parcels to cover debts and a speeding up of land consolidation in the region.
\end{abstract}

Key Words: Amazon; environmental licensing; highly optimized tolerance; property size; ranching; Rondônia

\section{INTRODUCTION}

Colonization in the Brazilian Amazonian state of Rondônia has occurred over decades, partly organized through the Brazilian Institute for Colonization and Agrarian Reform (INCRA) and other private agencies, and partly ad hoc, with landless migrants following access roads and staking claim by clearing land (Schmink and Wood 1992). This diversity in endowments, coupled with decades of land parcels bought, sold, and inherited (Browder et al. 2008), has led to a broad distribution of rural property sizes in the region, with different modes of production (Ellis 1993) and differing capacities to respond to shocks and stressors. Even within what are considered formally to be small, family farms, i.e., farms up to 240 ha in Rondônia, there is considerable diversity in farm size, production, and capacity.

I propose a model for family farms that operationalizes the concept of 'robustness trade-offs' (Janssen et al. 2007) to explain adaptations taken by family farms to improve their robustness, or resilience, to a set of expected stresses. Where resources are limited, such trade-offs reduce capacity to deal with other stressors, bringing them closer to a state of highly optimized tolerance (HOT; Carlson and Doyle 1999, Janssen et al. 2007), where adaptations to improve robustness to expected disturbances, such as poor yields or market prices, introduce new sensitivities to other disturbances, such as shifts in input prices. I argue that the limited resources of households on smaller properties, coupled with typical adaptations of diversification and intensification in land use and effort (Ellis 1993), bring smaller properties closer to HOT states, and leave them more vulnerable to collapse.
I look for support for this HOT farm model in fieldwork completed in the spring of 2009 in three municipalities in the Rondonian 'post-frontier' (Browder et al. 2008), where owners of small family farms answered questions regarding the use and production on their land, their investment of effort, and the history of change on their properties. Finally, I illustrate a case, topical at the time of writing, where this application of HOT can be of value, i.e., the debate over exceptions to be made for small farms in the requirements of Rondônia's environmental licensing for rural properties (LAPRO).

This paper extends the work of Janssen et al. (2007) to make more explicit the link between rural smallholder production and HOT, and uses it to examine the change in resilience of smallholder production in response to multiple stressors. It contributes the resilience perspective to the small wealth of literature on farm structural change in Amazônia (e.g., Walker et al. 2002, Muchagata and Brown 2003, Browder et al. 2008), and aims to inform debate on the special consideration necessary for small farms within the policy setting.

\section{BACKGROUND}

\section{Frontier colonization}

The historical process of colonization of the Amazon and expansion of the agricultural frontier has been well documented. Driven by a desire to cement Brazil's claim to the Amazon, massive colonization projects in the 1970s and 1980s brought thousands of migrant families to the region. Demand for land soon outstripped the capacity of the colonization projects to place families, and settlers from 
outside the region were able to lay claim to land simply by clearing and thus "improving" it (Schmink and Wood 1992, Caldas et al. 2007). When policy shifted in the mid 1970s away from small farmers and toward more formal granting of land titles to larger ranching, mining, and other operations (Schmink and Wood 1992), conflicts began to arise over claims by farmers who had occupied an area only to have the title granted to someone else. The government generally issued compensation to the small farmer for their "improvement" of the land and upheld the larger firm's land title to settle these claims (Schmink and Wood 1992). This created a perverse incentive for small farmers to deforest land, receive compensation for their work in clearing the land, and drop further back into the forest to repeat the cycle. The result, across more than 40 years of settlement, is a broad landscape with varying degrees of agricultural development and abandonment, and vast areas stripped of forest cover.

\section{The Rondonian agricultural landscape as a resilient, HOT system}

Rondonian family farms range in size from one or two up to several hundred hectares (IBGE 1996). A classic model for understanding farm size and production as a function of family life cycle is that of Chayanov, but as noted by Walker et al. (2002), it is insufficient for much of Amazônia because it does not include access to labor markets. In fact, the 'extended urban' character of many settlements in the Rondonian postfrontier mean significant opportunities to hire additional labor, to work away from the farm, and access to more complete markets for production (Monte-Mór 2004, Browder et al. 2008). However, some basic principles of rural economics can be expected to hold: for example, as property size increases, productivity and land use intensity shift (Ellis 1993), with smaller properties making more intensive use of their scarcer land resources. This prediction has borne out in empirical research within the region; Sills and Caviglia-Harris (2008) reported land values per hectare to be significantly negatively correlated with property size on family ranches in Rondônia. Access to labor markets in contemporary Amazônia lets these shifts in land use intensity across property size be accompanied by shifts in the allocation of family labor among on-farm and off-farm activities (Ellis 1993). I argue that these movements signal a shift for these properties toward being in a HOT state (Carlson and Doyle 1999).

As Carlson and Doyle (1999:2529) describe them, HOT systems are "robust to perturbations they were designed to handle, yet fragile to unexpected perturbations and design flaws." As HOT systems adapt to anticipated stresses, new sensitivities or 'design flaws' are introduced; the intensification of production using fertilizers, for instance, introduces sensitivity to fluctuations in fertilizer cost. Janssen et al. (2007) refer to such shifts as 'robustness trade-offs', capturing the idea that shifting resources to adapt to one stressor necessarily leaves fewer resources to cope with others. I propose the following model of a 'HOT farm' to describe agricultural conditions on smaller properties in the Rondonian postfrontier, discussing both the on-farm and off-farm strategies smallholders may employ as adaptations, and hypothesizing on how aspects of this model would be expected to manifest in empirical study of the region. In this model I identify HOT states with emerging fragility to disturbance; that is, although I expect that all agricultural systems make robustness trade-offs, it is the extent to which those trade-offs make them sensitive and fragile to new disturbances that defines them as HOT.

\section{Farm production model}

The model of farm production upon which I base discussion of HOT is as follows (Fig. 1). At its most basic, farm economic production is a direct function of the size of the farm, subject to market and climate forces. This production, more specifically the surplus above household needs, is a major component shaping household resilience and the capacity to cope with and adapt to stressors. One strategy, important when there are not more liquid assets from which to draw, to address stresses, such as illness or the breakdown of equipment, as they arise is to sell land parcels to raise cash or purchase land when opportunity arises, and this most basic set of processes forms an archetypal 'success to the successful' loop. Farmers that do well can purchase more land and can increase their production, and farmers that do poorly must sell land and compromise their means of production in what is otherwise known as a positive feedback, or reinforcing loop (identifiable by the even number of negative signs in Fig. 1). In this way, farm size becomes partially endogenous over time, determined in part by the set of options implicit here within farm household resilience, though within any given period it is exogenous,

i.e., the current resilient state of a farm household does not determine current farm size.

Some of the important ways farmers act to overcome this feedback and maintain their state, particularly on smaller farms, are to intensify and diversify both on-farm, i.e., crops and livestock, and off-farm, e.g., wage labor, means of production. The capacity to make these adaptations is not a given; for example, the purchase of different seeds entails an up-front cost and a risk that some farmers may not be able or willing to take, and this model notes that the ability to make these choices is tied directly to farm household resilience. The motivation for intensifying or diversifying production is that it can increase farm economic production, given uncertainties in market prices and climate; where intensification and diversification emerge as responses to smaller property size, they form negative feedback, or balancing loops (identifiable by an odd number of negative signs), allowing farms to maintain production and resilience even when property size is smaller. 
Fig. 1. Causal loop representation of farm model. Connections with a + sign denote direct effects (as A goes up, B goes up) whereas connections with a - sign denote inverse effects (as A goes up, B goes down). Processes exogenous to the farm system are shaded gray. The dashed lines for the intensity and diversity processes indicate that although there may not exist a simple + or - causal relationship among these processes with resilience, there does exist some threshold resilience or capacity below which these strategies are not available, for example, where farmers are unable to invest in additional seed or inputs with which to diversifv or intensifv their crops.

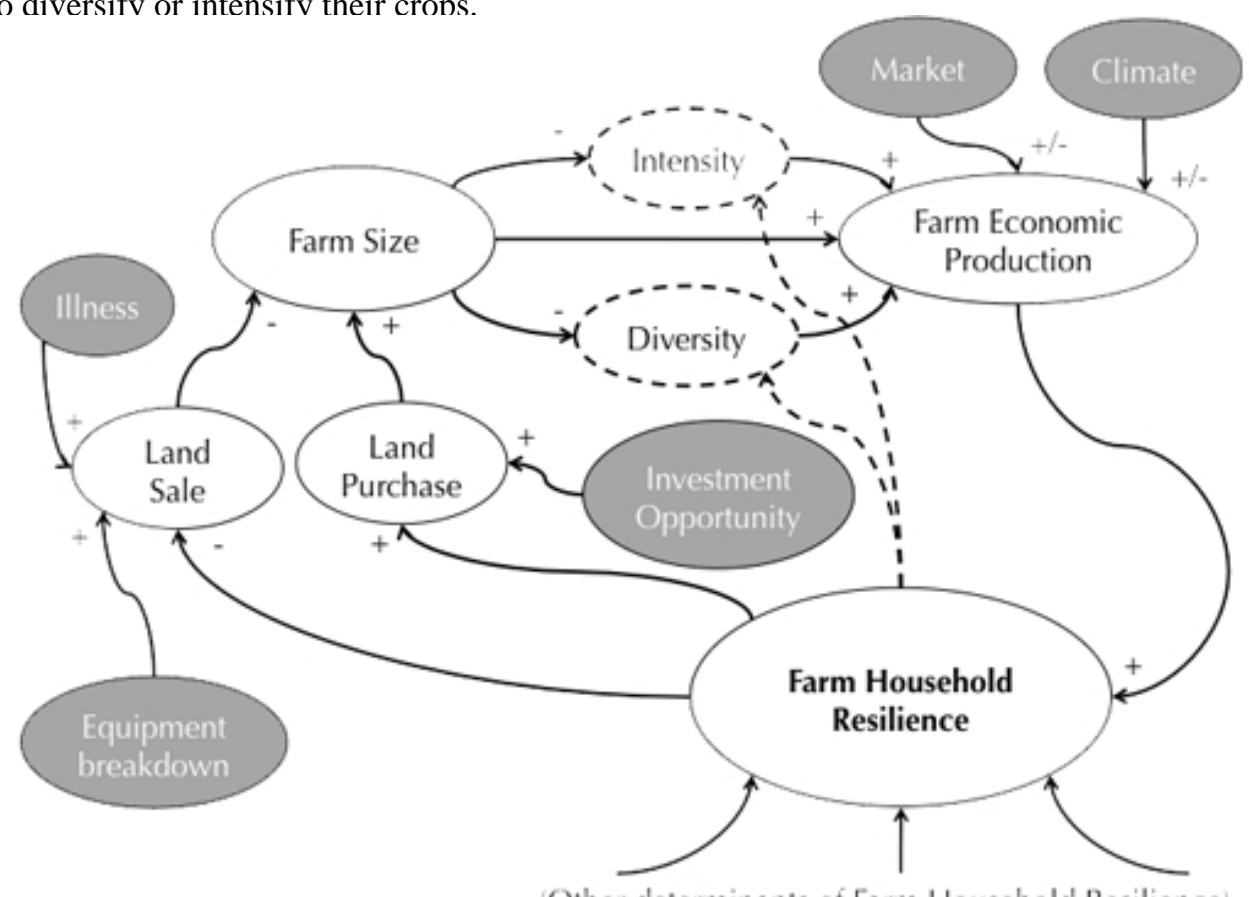

(Other determinants of Farm Household Resilience)

\section{On-farm strategies: the example of crop diversification}

Crop diversification is a means to reduce uncertainty associated with the yield of any one particular crop (Ellis 1993). Yield is a function of a large number of factors, e.g., climate, soils, inputs, etc., many of which average out to some extent over larger areas, making yield uncertainty a greater issue for smaller properties (Fig. 2A). For these smaller properties, it can be beneficial to diversify production away from some revenue-maximizing product $\mathrm{X}$ and into other marketable commodities. Mathematically, diversifying into new activities can reduce risk when variability in yields within the new activity is lower, or when the diversification spreads risk among activities where variability in yields is not expected to co-vary (see Appendix 1 for a full development of the mathematics of diversification). In doing so, costs may rise with for example, additional seed, inputs, and labor to plant new crops in rotation or intercrop, and revenues may be reduced, i.e., new crops may be less lucrative than product $\mathrm{X}$ (Fig. 2B), so that the cash surplus for small farms above their basic needs may be reduced. This is not without exception; agroforestry is a salient example where synergies among the ecological and development needs of different crops grown together can lead to potentially greater marginal returns to the farmer on land and labor (e.g., Browder and Pedlowski 2000,
Browder et al. 2005). However, it must be noted that there often do not exist markets for many of the products of agroforestry systems (Torquebiau and Penot 2006), limiting their broader appeal to small farmers. However, even considering a potential reduction in cash surplus, farms with diversified production become more resilient (less sensitive) to uncertainty in yield of product $\mathrm{X}$, because their incomes now depend significantly upon other sources (Fig. 2C). A similar argument as this for crop diversification may be constructed for dealing with price uncertainty in commodity $\mathrm{X}$.

This resilience to expected uncertainties in yields comes with costs, i.e., production likely becomes more intensive, requiring additional labor and inputs, and allowing less land to lie in fallow at a given time, though it is worth noting that only the more immediate of these costs may factor into the decisions of a farmer with limited resources and a higher discount rate upon the future. Thus, the intensified farm becomes sensitive to a new set of potential disturbances, such as shifts in the costs of labor or fertilizer. The returns to intensification also have limits. Additional inputs of labor and chemicals yield diminishing returns even as costs may continue to smoothly increase (Fig. 3A), and may eventually, as in the case of overfertilization, lead to additional costs or externalities. 
Fig. 2. Diversification by farms to reduce vulnerability to yield uncertainty. A) Yield uncertainty is greater for smaller farms. B) Costs increase with additional inputs required for diverse crops, and revenues may drop as effort allocated away from profit-maximizing product X. C) Resilience to collapse (in this case, revenues) is less sensitive to drops in yield of product X for more diversified farms.
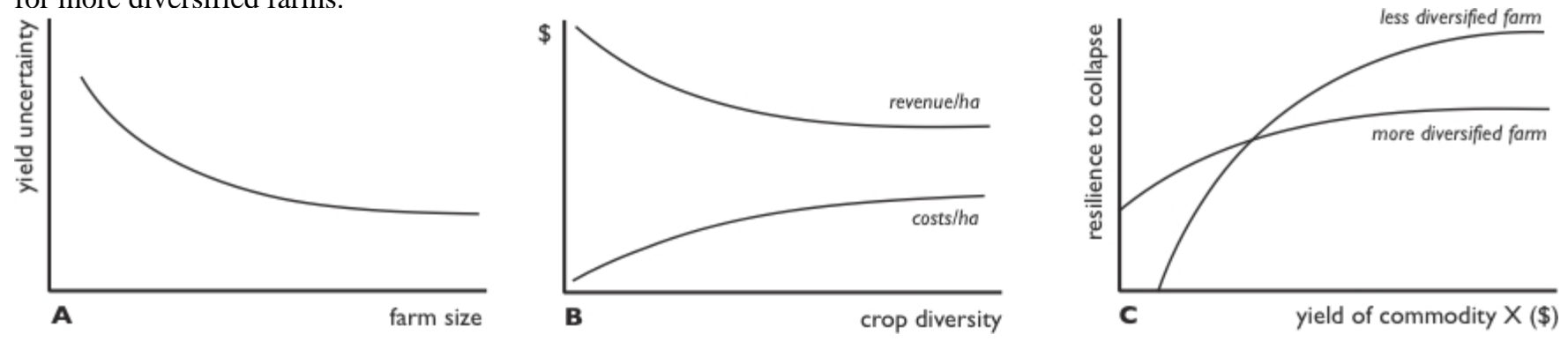

Further, the landscape itself may exhibit a threshold response to overuse (Scheffer et al. 2000), where degraded land must be significantly rehabilitated and intensity dropped well below previous levels of use before it can be productive again (Walker et al. 2004). Together, these economic and ecological constraints place upper boundaries on the extent to which farms can intensify. At the other end, intensity is bounded below by the household needs of the farm family. Such basic household needs can be expected to be similar across most farming households, meaning that farms with less land will need to intensify more than those with more land to meet those fixed minimal needs. Thusly, the lower boundary on production intensity, that is, to be a viable household, is higher for smaller properties than for larger ones.

This argument leads to the proposition that along this dimension, smaller properties approach what might be considered a HOT state, and the following hypotheses:

H1: Land use intensity, measured both through inputs, i.e., labor, maintenance, and chemical input use per hectare, and outputs, such as the value of production per hectare, is higher for smaller properties, and the range of intensities over which properties can remain viable is reduced for smaller properties, and skewed toward higher density (Fig. 3B).

$\mathrm{H} 2$ : The reduced surplus above basic household needs that smaller properties accumulate can mean a lower resilience to farm collapse overall relative to larger properties.

In the language of Walker et al. (2004), smaller farms have both lower latitude, i.e., the width of the basin of attraction of a stable state; here, the range of intensity over which a farm can be viable, and lower resistance, i.e., the difficulty in shifting the system out of the basin of attraction; here, the financial surplus above and beyond basic household needs, to system change.

Off-farm strategies: agricultural labor and urban employment

Where employment opportunities exist, and where farmers perceive the risk of engaging in the labor market to be worthwhile, households may invest as well in off-farm employment, thus further diversifying the investment of their efforts. As Ellis (1993) describes, farm households seek out off-farm opportunities when the expected return to off-farm labor is greater than returns from the same effort on-farm; formally, when the likelihood of finding work, $p$, times the wage rate, $w$, is greater than the average value product of labor on the farm. For smaller farms where production is more intensive, and thus both the marginal and average products of labor are comparatively low, we would expect to see more effort invested in off-farm labor, and a willingness to accept labor at a lower wage rate.

H3: Effort intensity is higher for smaller properties, both through greater labor intensity on-farm, and through higher engagement in off-farm employment at the expense of leisure.

From the perspective of robustness trade-offs and HOT, the act of engaging in off-farm employment to improve household returns to effort is another step toward a HOT state. The additional income increases household resilience to an expected set of shocks such as to prices or yields, which reduce cash and food surpluses, by providing an additional source of income, but introduces vulnerability to a new set of shocks, i.e., shifts in the labor market and availability of labor opportunities. Additionally, where off-farm employment means agricultural labor on other farms, these opportunities may be subject to the same forces that may govern price and yield shocks on the household farm, and thus may not exist to fall back upon when the farm is struggling. Thus, off-farm opportunities may offer resilience improvements by allowing households to intensify their effort, substituting wage labor for on-farm work or leisure, rather than simply intensifying their use of land, but still push farms toward a HOT state.

\section{Robustness in larger farms: HOT states?}

The above discussion has focused on the types of adaptations typical of smaller properties and illustrated how they push household farms toward a HOT state. However, farms across all scales make adaptations and robustness trade-offs, so it is important to state briefly here what makes larger properties 
Fig. 3. Resilience drops as a function of intensity. A) Returns to intensification (production/ha) diminish, and cost structures differ between small (unmechanized) and large (mechanized) farms. Differences in property size and costs mean that the lower boundary on intensity (to meet basic household needs) will differ across farms of different sizes. Differences in costs may mean that the upper boundary on intensification differs also. B) Smaller farms exhibit a narrower range of viability (latitude) with respect to intensitv than larger farms. and lower resilience (resistance) to collabse.
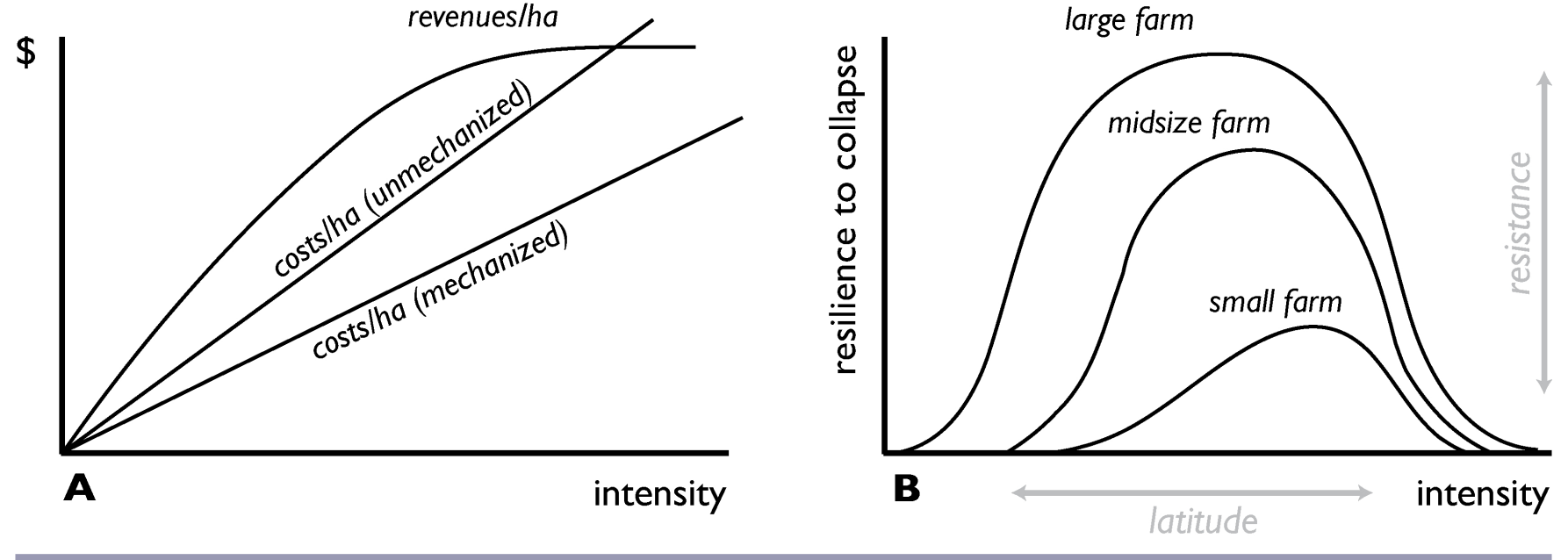

less HOT, i.e., less fragile, than those that are smaller. In Rondônia, the typical path for larger properties is to specialize in cattle production, for either or both beef and dairy production (Faminow 1998, Walker et al. 2000). Specialization in cattle makes these farms more vulnerable to shocks in market prices for beef and dairy, as well as to shocks in climate that impede cattle grazing and development. However, does this specialization make these farms more fragile and at greater risk?

As Muchagata and Brown (2003) note, the view of cattle is that they carry with them a low risk compared with crop production, that cattle prices are stable and markets easily accessed, and that the dual production of beef and dairy brings some flexibility within the specialization. Using the mathematics developed in Appendix 1, cattle have low variability in their expected return, $\mathrm{f}$, but a very high initial investment cost, I. In this sense, specialization in cattle production is something of a privileged adaptation to the same sets of shocks, i.e., price and climate, to which smaller farms must adapt. The ability to cover the initial investment costs, I, give access to an activity with lower variability in expected return, allowing the farmer to reduce risk by specialization in a low risk activity, rather than by diversifying among a set of higher risk activities.

Beyond this, it must also be noted that many of the risks of climate average out to a certain degree for larger properties (further reducing variability in $\mathrm{f}$, see Appendix 1), and that larger farms simply have more resources. Cattle and land are common means of storing wealth in Amazônia, and their sale is a common response to various needs and crises as they arise, e.g., an illness in the family, the breakdown of a truck, or even an investment opportunity (Walker et al. 2000, D'Antona et al. 2006, Browder et al. 2008). The ability to sell cattle or land to meet the unexpected needs of the household without undermining the family's means of production is a meaningful signal of household resilience.

H4: Larger properties suffer less impact on their means of production when responding to unexpected stressors or opportunities.

Along these lines, it should be clear that the investment in cattle that typically follows increased property size in Amazônia brings with it vulnerabilities to a similar set of shocks faced by households on smaller properties, though these larger households suffer less risk to such climate and price shocks and have more resources to respond to other shocks to the household.

In sum, all farms in the system are making robustness tradeoffs, choosing a set of crops or animals or employment options in which to invest, and the intensity with which to do so, based on an expected set of disturbances in market, climate, or other exogenous forces. However, smaller properties do so with fewer resources to allocate, and often with less privileged options in which to invest, e.g., crops as opposed to cattle. These smaller properties intensify and diversify more than larger properties, but the limitations of what they can generate on their limited land, and with their limited time to commit to wage labor, mean that their economic production and surplus above household needs will generally be lower than that for larger properties. This can translate, when faced with a stress demanding a response, into fewer response options and the possible need to sell off part of the farm property; the sale of 
land cuts into the means of production more significantly with decreasing property size. This increased fragility in responding to stress is what signals the more HOT state of the smaller properties. The following sections present empirical results from my sample in the Ji-Paraná River Basin that test hypotheses $\mathrm{H} 1-\mathrm{H} 4$ and illustrate the shift toward a HOT state that occurs with decreasing property size.

\section{METHODS}

\section{Survey methodology}

The study survey team conducted interviews with a sample of 234 smallholders across three municipalities (Fig. 4): JiParaná (72 interviews), Machadinho D’Oeste (88 interviews), and Cacoal (74 interviews), in the Ji-Paraná River Basin between the months of February and April 2009.

Fig. 4. The Ji-Paraná River Basin. Study sites are indicated with a hatched pattern. Inset maps to the right illustrate lot delineation patterns characteristic of (from top to bottom)

Machadinho. Ji-Paraná. and Cacoal. respectivelv.

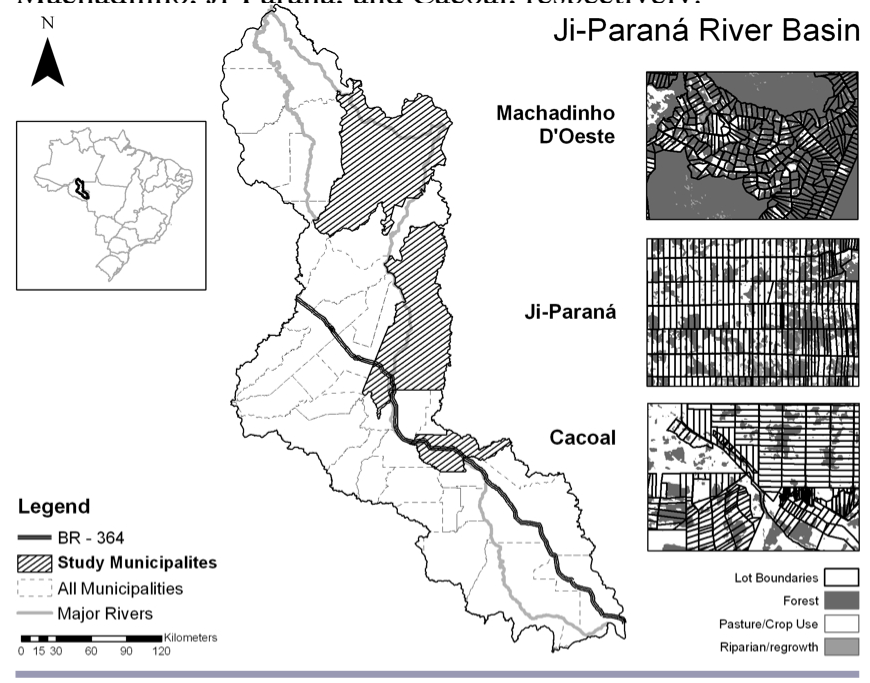

The survey was administered in partnership with the Federal University of Rondônia (UNIR) and the Rondonian agency for rural extension and technical assistance (EMATER-RO). Most interviews were solicited from smallholder producers visiting EMATER-RO local offices in each of the three municipalities, while a small number of the interviews were solicited from smallholders during EMATER public seminars and site visits. Each interview took approximately one hour and respondents were asked a set of questions about their claim to their lands; their production and access to credit; their responses to climate and economic stresses; their use of information; and their understanding of various issues including global climate change as well as state and federal agricultural and water policy. Interview results were poststratified for property size.

\section{Limitations of survey methodology}

Our team was unable to obtain lists of farmers from local agricultural syndicates, cooperatives, or from EMATER-RO; additionally, we did not have the resources, i.e., money or vehicles, to perform a truly random sample across the agricultural landscape. Our negotiated partnership with EMATER-RO allowed us to interview a large sample within a limited budget, but the design introduces some important limitations on the dataset.

The survey as implemented gives an opportunistic sampling across family farm households who regularly interact with EMATER-RO, but excludes households that do not rely on rural extension services. If we consider EMATER-RO to be important brokers of information regarding rural credit and agricultural techniques, then there are several alternatives to consider. It may be that our sample excludes family farms that have less access to this important information, skewing our sample to farms that may be slightly better off. Alternatively, it may simply be more successful farmers who do not need access to credit or rural assistance and choose not to be connected with EMATER-RO. Without more knowledge of the population excluded from the sample frame, it is not possible to state confidently the form of the bias introduced through the opportunistic sample, and we must note that our results should be restricted to considering the substantial subset of local farms that are in contact with EMATER-RO.

A further limitation introduced by interviewing farmers at EMATER-RO offices is that the survey does not note the locations of the farms or their distances from major roads or urban centers. Thus, it is not possible to control for any Von Thunen-type effects from the sample, where increasing land values closer to urban centers select for smaller properties and more intensive production, an additional factor in explaining intensity on smaller properties. The majority of land purchases have been small parcels exchanged among neighbors, i.e., 75 of 90 transactions are less than 50 ha in size, and only 4 of 90 are 100 ha or larger. This trend coupled with the regularity of initial land endowments during colonization does not suggest a pattern of consistent subdivision in one area and aggregation in another, which would fit a Von Thunen pattern, within the scale range of family farms. We would expect this effect, i.e., spatial autocorrelation of property size and intensity, to be more important across the scale range from family farms through medium- to large-scale farms, because more properties are formed through the aggregation of individual lots allocated during colonization. However, it is noted that a study with the relationships and resources to undertake site visits at individual properties would facilitate better control over this potentially confounding effect and provide better resolution of the phenomena of interest. 
Table 1. Sobel test results for significance as mediating variables of property size on production intensity (measured by the raw value of production (VOP) per hectare), controlling for household demographic (measured by age of head of household) and access to credit (measured by whether respondent had accessed credit in last 10 years). Predictors significant at $90 \%$ confidence are marked in bold-face type. Coefficients 'a' determined by regression of mediator variable against control variables and IV; coefficients 'b' determined by regression of DV against mediator and control variables and IV.

\begin{tabular}{|c|c|c|c|c|c|c|}
\hline \multirow[b]{2}{*}{ Mediator } & \multicolumn{2}{|c|}{ Predicting mediator using IV } & \multicolumn{2}{|c|}{ Predicting DV using mediator and IV } & \multirow[b]{2}{*}{ t statistic } & \multirow[b]{2}{*}{$\mathrm{p}$ value } \\
\hline & Coefficient a & Standard error of a & Coefficient $b$ & $\begin{array}{c}\text { Standard error of } \\
\mathrm{b}\end{array}$ & & \\
\hline $\begin{array}{l}\text { Maintenance Costs (per } \\
\text { hectare) }\end{array}$ & -4.1512 & 1.198 & 1.5997 & 0.3355 & -2.8039 & 0.0050 \\
\hline Input costs (per hectare) & -0.6032 & 0.2414 & 7.8699 & 1.8149 & -2.1650 & 0.0304 \\
\hline $\begin{array}{l}\text { Contracted Labor (per } \\
\text { hectare) }\end{array}$ & -0.0314 & 0.015 & 152.22 & 24.7799 & -1.9587 & 0.0502 \\
\hline $\begin{array}{l}\text { Family Labor (per } \\
\text { hectare) }\end{array}$ & -0.0796 & 0.0177 & 35.2011 & 23.1938 & -1.4377 & 0.1505 \\
\hline Income / Entropy & -0.0019 & 0.0007 & -1670.5 & 423.0107 & 2.2683 & $\mathbf{0 . 0 2 3 3}$ \\
\hline
\end{tabular}

\section{Study sites}

The three sites were chosen to be as representative of the diversity of activities within the Ji-Paraná Basin as possible, subject to the constraint that research is not generally permitted in municipalities that lie within $150 \mathrm{~km}$ of the border that Rondônia shares with Bolivia. The city of Ji-Paraná is Rondônia's second most populous city and the most urbanized municipality in the basin, with growth and development influenced both by the opening of the BR-364 highway in 1960 and by the implementation of official colonization projects beginning in the 1970s. It produces the most livestock and has the second-greatest crop production out of all municipalities in the state (IBGE 1996).

The other two sites, Machadinho and Cacoal, were the result of official colonization projects implemented both by the federal Institute for Colonization and Agrarian Reform (INCRA) and, to a lesser extent, by privately initiated colonization projects in the 1970s and 1980s (INCRA 1998). Benefiting from the existing infrastructure of the BR-364, Cacoal has grown to produce more crops, mainly coffee, than any of the other municipalities in the state, and has the secondlargest livestock production (IBGE 1996).

Machadinho D'Oeste (henceforth Machadinho) lies farther from the belt of development that followed construction of the BR-364 and closer to what would be considered the Amazonian agricultural frontier. A much smaller and younger settlement than the other two sites, official colonization projects did not begin in Machadinho until 1982, as part of the World Bank-funded POLONOROESTE plan (EMBRAPA 2009).

\section{Data presentation}

Drawing from the HOT farm model presented above, I look at a number of variables that signal farm resilience to understand where farms in the Rondônia sample lie with respect to HOT states. As indicators of input intensity, I examine the per-hectare maintenance and input costs, the use of family and contracted labor, and the stocking density of cattle. I calculate the raw value of production to indicate production intensity, and as well calculate the entropy (Galtung 1980, Bailey 1983) in income as a measure of crop diversification. I look at the proportion of farms accessing offfarm income opportunities, as well as the average number of paid days of agricultural labor undertaken by households, as indicators of income diversification. Finally, I examine past land purchases and sales, as indicators of farm structural change.

In the results that follow, the data are grouped into logarithmically spaced bins for properties up to $15 \mathrm{ha}, 30 \mathrm{ha}$, $60 \mathrm{ha}, 120 \mathrm{ha}$, and properties larger than 120 ha in size; the data are presented as vertical bars representing mean values or proportions. Farm sizes in Brazil are commonly expressed in terms of fiscal modules (one fiscal module $=60$ ha in Rondônia), so that this spacing maps onto properties consisting of $1 / 4,1 / 2,1,2$, and greater than 2 fiscal modules, respectively. In some cases, data from each site are presented separately in groups. In other cases, several different variables are presented together on the same chart; in these cases, only the average data across all three sites are presented, for reasons of space, flow, and clarity. However, all data broken down by site along with basic statistics are tabulated in Appendix 2. Error bars are not shown in images, but the results of difference-of-means tests among bins are attached as Appendix 3. Additionally, results that test the significance of the indicators of intensity and diversity as mediating variables for property size on production intensity (using the Sobel test) are shown in Table 1.

The tags ' $n$ ', ' $\mathrm{n}_{\mathrm{JP}}$ ', 'n $\mathrm{n}_{\mathrm{MA}}$ ', and ' $\mathrm{n}_{\mathrm{CA}}$ ' indicate the number of data points from which the bars across all three sites, for Ji-Paraná, for Machadinho, and for Cacoal, respectively, were derived. Where appropriate, a percentage in brackets indicates the 
proportion of the overall sample for that bin that was used, either where the particular question only applies to a subset of respondents, or where data were rejected because of responses that were missing or could not be understood.

\section{FARM CHARACTERISTICS}

\section{Property size and land use}

The Ji-Paraná and Cacoal samples are fairly evenly distributed across size classes, whereas the distribution of the Machadinho sample is clustered much more tightly around the original lot allocation size for the Machadinho settlement of 50 ha; less time has passed for land to be subdivided (Appendix 2). Land use across scale is similar in all three sites, with cropland in smaller properties giving way to pasture land as property size increases (Fig. 5). This follows the typical path discussed above and is in keeping with the model of farm evolution observed by Muchagata and Brown (2003) in Marabá, Pará, with higher proportions of land in pasture and specialization in cattle on older and larger family farms.

Fig. 5. Trends in land use across property size, aggregated across all three sites. Percent refers to the percent of surveys in each size class used to generate bars; $\mathrm{n}$ is the number of surveys used.

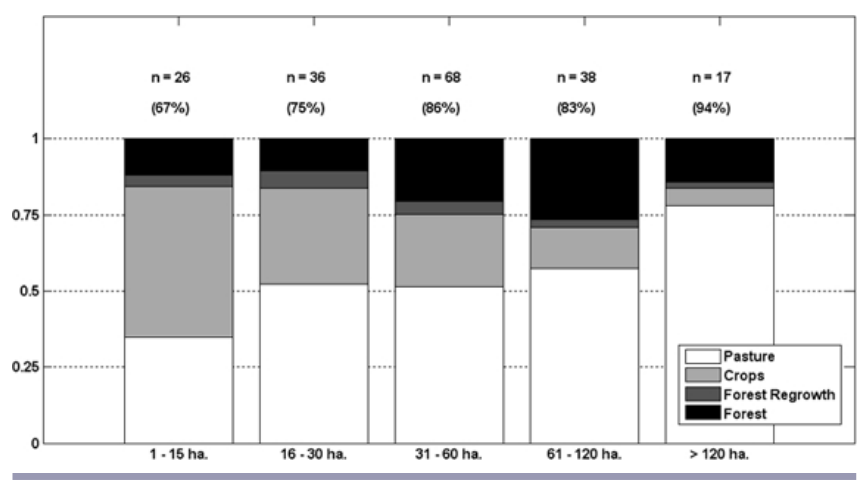

Consistent with the HOT farm model and supporting H1, land use intensity, measured by the per-hectare use of inputs, including herbicides, fungicides, insecticides, chemical fertilizers, as well as mineral salts and vaccines for livestock (Fig. 6), and in overall annual maintenance costs (Fig. 7), is significantly higher for properties smaller than 30 ha (Appendix 3), and is a significant mediator of property size on production intensity (Table 1 ). The sharp rise in costintensity for small properties in Ji-Paraná is driven by a small number of urban chicken-rearers and horticulturalists whose capital- and input-intensive production systems are expensive to maintain.

\section{Labor use}

Labor use intensity decreases with increasing property size (Figs. 8 and 9); family labor is significantly more intensive on properties smaller than 30 ha (Appendix 3), which, together with the land use intensity results in Figures 5 and 6, signals

Fig. 6. Average investment in inputs (herbicides, insecticides, fungicides, chemical fertilizers, mineral salts, and vaccines) per hectare, annually. Percent refers to the percent of surveys in each size class used to generate bars; $\mathrm{n}_{\mathrm{JP}}, \mathrm{n}_{\mathrm{MA}}$, and $\mathrm{n}_{\mathrm{CA}}$ are the number of surveys used from each of Ji-Paraná, Machadinho, and Cacoal, respectively.

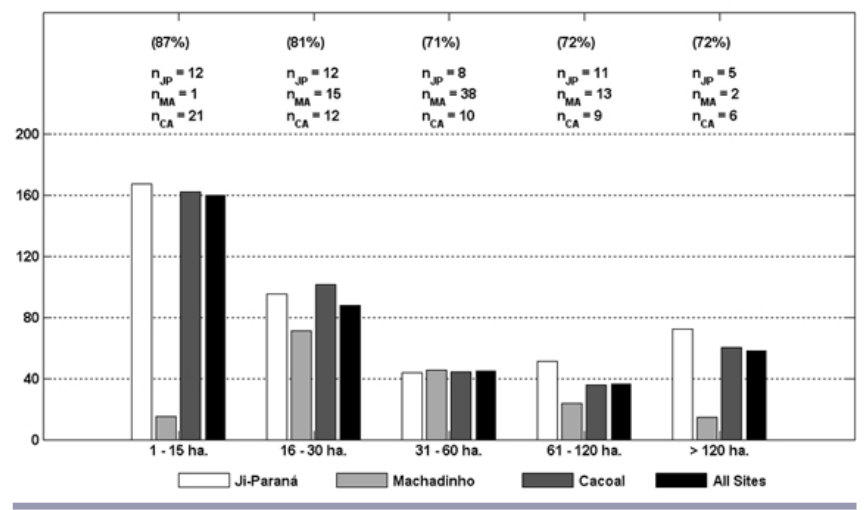

Fig. 7. Maintenance cost per hectare, annually. Percent refers to the percent of surveys in each size class used to generate bars; $\mathrm{n}_{\mathrm{JP}}, \mathrm{n}_{\mathrm{MA}}$, and $\mathrm{n}_{\mathrm{CA}}$ are the number of surveys used from each of Ji-Paraná, Machadinho, and Cacoal, respectively.

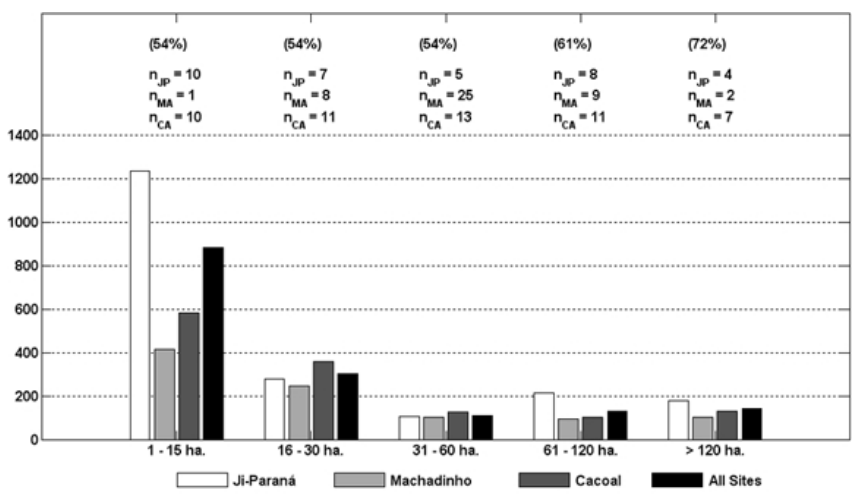

an underutilization of land and a shift away from it being a scarce resource for larger properties (Ellis 1993). Contracted labor intensity is a significant mediator of property size on production intensity (Table 1), whereas family labor is not. Comparing Figure 9 with Figure 8, the ratio of family labor to contracted labor decreases with increasing property size, reflecting the shift from peasant production toward a more market-integrated capitalist family enterprise. 
Fig. 8. Person-days of contracted labor per hectare, annually. Percent refers to the percent of surveys in each size class used to generate bars; $\mathrm{n}_{\mathrm{JP}}, \mathrm{n}_{\mathrm{MA}}$, and $\mathrm{n}_{\mathrm{CA}}$ are the number of surveys used from each of Ji-Paraná, Machadinho, and Cacoal, respectively.

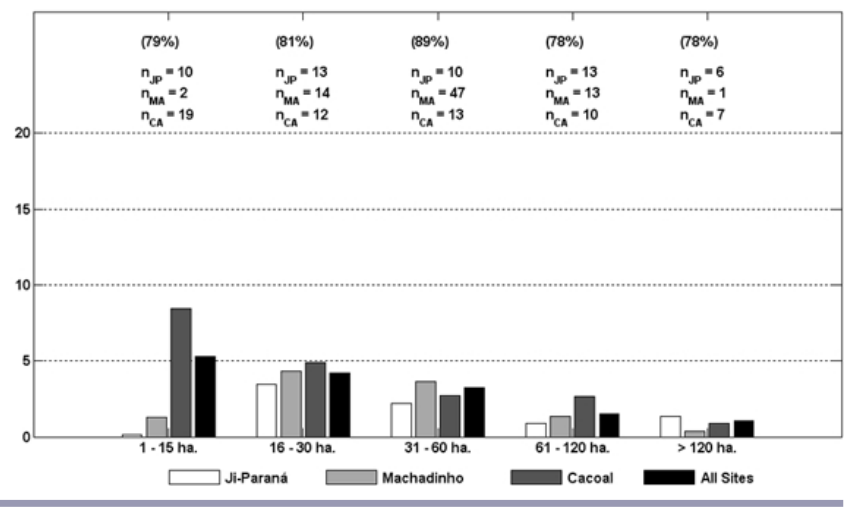

Fig. 9. Person-days of family labor per hectare, annually. Percent refers to the percent of surveys in each size class used to generate bars; $\mathrm{n}_{\mathrm{JP}}, \mathrm{n}_{\mathrm{MA}}$, and $\mathrm{n}_{\mathrm{CA}}$ are the number of surveys used from each of Ji-Paraná, Machadinho, and Cacoal, respectively.

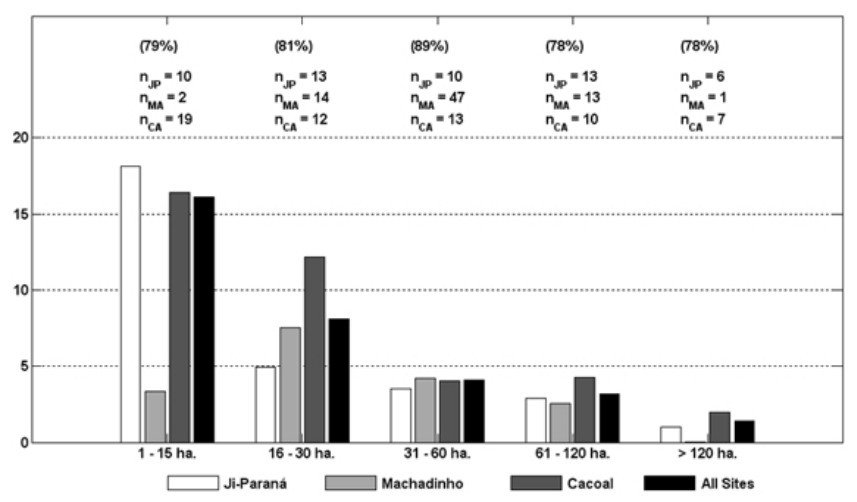

Figures showing labor use broken down by pasture and cropland are included in Appendix 4.

\section{Farm production}

The proportion of farms engaging in cattle ranching increases smoothly to encompass all properties above 120 ha in size (Fig. 10), but the density of cattle (in head per hectare) is generally lower for larger properties (Fig.11), with density significantly higher on properties $15-30$ ha in size than on those larger (Appendix 3). This is most clear in Ji-Paraná, where stocking densities drop from around four to around two head per hectare as property size increases.
Fig. 10. Proportion of properties raising cattle. Percent refers to the percent of surveys in each size class reporting the raising of cattle; $\mathrm{n}_{\mathrm{JP}}, \mathrm{n}_{\mathrm{MA}}$, and $\mathrm{n}_{\mathrm{CA}}$ are the number of surveys used from each of Ji-Paraná, Machadinho, and Cacoal, respectively.

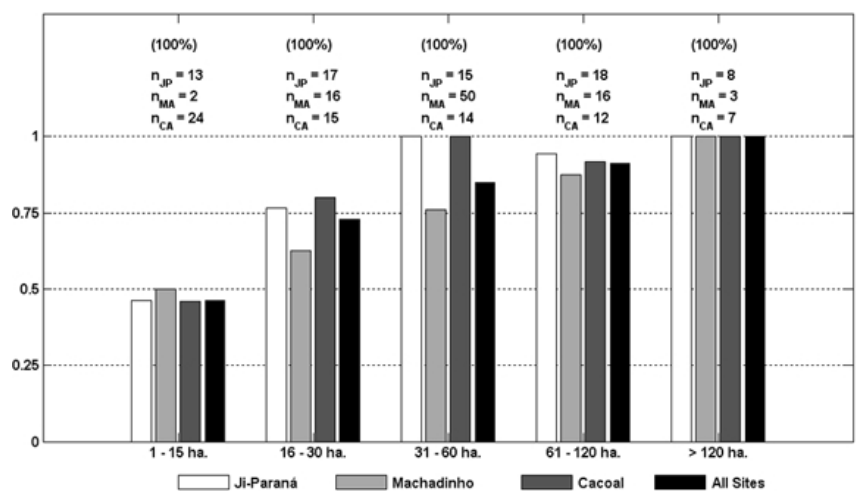

Fig. 11. Cattle stocking density on cattle raising properties. Percent refers to the percent of surveys in each size class reporting the raising of cattle; $\mathrm{n}_{\mathrm{JP}}, \mathrm{n}_{\mathrm{MA}}$, and $\mathrm{n}_{\mathrm{CA}}$ are the number of surveys used from each of Ji-Paraná, Machadinho, and Cacoal, respectively.

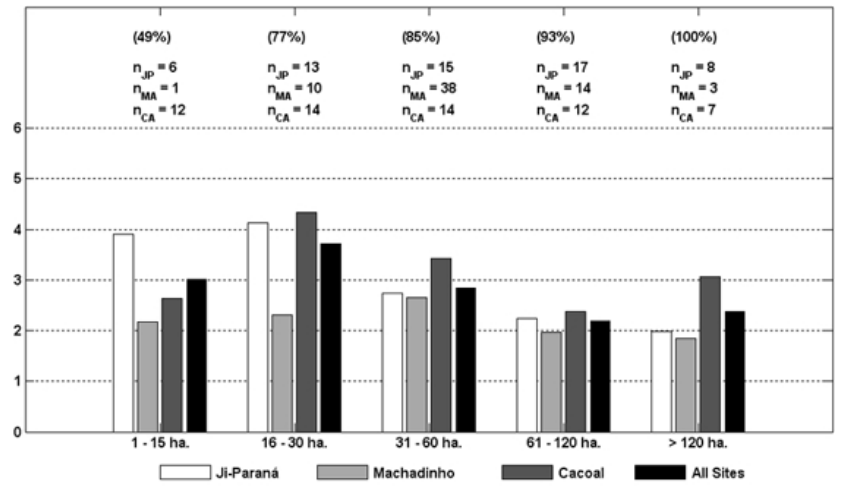

In general, production intensity decreases as farms increase in size, in keeping with the HOT farm model and further supporting $\mathrm{H} 1$. The raw value of production (VOP) is calculated here as the sum of farm production multiplied through by each product's per-unit economic value:

$$
V O P=\sum_{i} M_{i} \cdot P_{i}
$$


where $M_{i}$ and $P_{i}$ are the mass produced and per-unit price for product $i$. The per-unit price is estimated here as the average of the stated per-unit price reported by farmers across the sample. VOP per hectare in the sample is significantly higher in properties less than 15 ha in size than in all others (Fig. 12, Appendix 3). A breakdown of VOP by product is included in Appendix 4.

Fig. 12. Raw value of production in $\$ R /$ ha. Percent refers to the percent of surveys in each size class used to generate bars; $\mathrm{n}_{\mathrm{JP}}, \mathrm{n}_{\mathrm{MA}}$, and $\mathrm{n}_{\mathrm{CA}}$ are the number of surveys used from each of Ji-Paraná, Machadinho, and Cacoal, respectively.

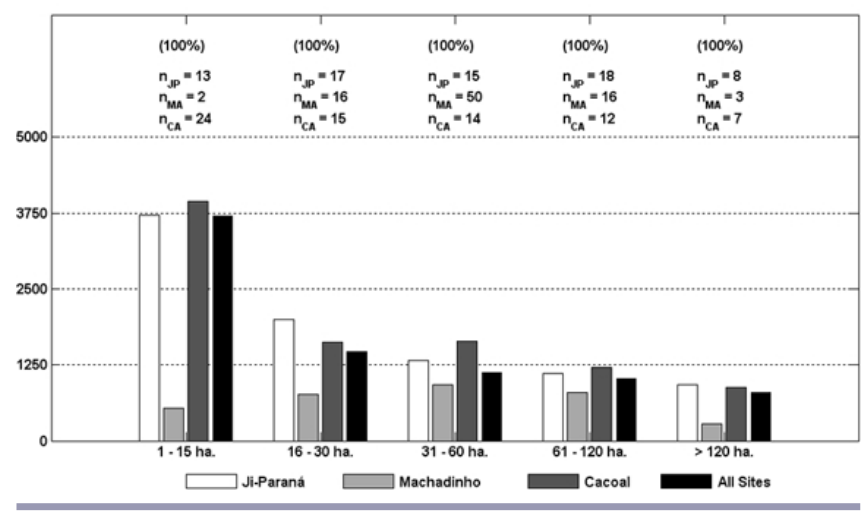

\section{Income diversification}

Diversity is measured in farm income as the income entropy $E$ :

$$
E=-\sum_{i} f_{i} \cdot \ln \left(f_{i}\right)
$$

where $f_{i}$ is the fraction of farm income derived from source $i$. Borrowed from its origins in thermodynamics (Rechberger 2001, Rechberger and Graedel 2002, Kaufman et al. 2008), entropy has been used in social science research as a measure of uncertainty (Bailey 1983, Gill 2005); of flexibility (Shuiabi et al. 2005); of inequality (Allison 1978); and, as I use it here, of diversity (Galtung 1980). The income entropy measure $E$ is equal to 0 when all income is derived from a single source, and is maximized when income is derived equally from a large number of sources. For example, when income is derived in equal parts from two different sources, $E=0.69$, and when derived in equal parts from ten different sources, $E=2.3$. Income entropy in Machadinho declines smoothly with increasing farm size, whereas Ji-Paraná and Cacoal both show single-peaked distributions for income entropy across farm size (Fig. 13), and a drop in income diversity for the smallest size class.
Fig. 13. Income entropy. Percent refers to the percent of surveys in each size class used to generate bars; $n_{J P}, n_{M A}$, and $n_{\mathrm{CA}}$ are the number of surveys used from each of JiParaná, Machadinho, and Cacoal, respectively.

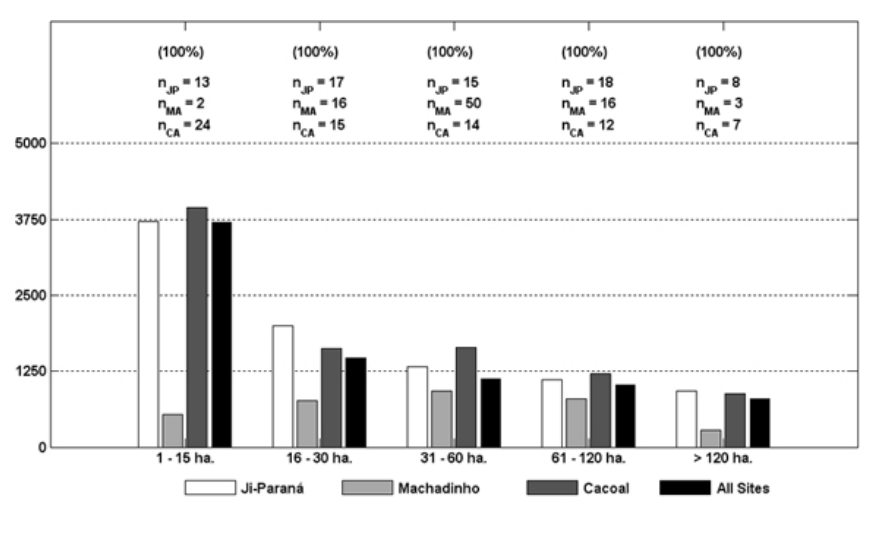

Properties 30-60 ha in size have significantly higher entropy than those larger (Appendix 3), and income entropy is a significant mediator of property size on production intensity (Table 1). As mentioned above, some of the very small properties in these classes are urban horticulturalists, operating small, specialized operations that irrigate from river water and grow in greenhouses to supply labor- and water-intensive products like salad greens; others are capital intensive chickhatching and chicken-raising operations. These examples of specialization at small scales highlight the departure that agriculture can take in urbanized regions from models like that of Muchagata and Brown (2003), where specialization follows an accumulation of property.

\section{Off-farm income}

Our survey did not include an explicit assessment of off-farm income levels, but did ask interviewees whether they derived income from outside of their farm; about half of participants across all size classes reported deriving either commercial, professional, or other such income in addition to production from their own farm. This unfortunately does not give a signal of how extensively these properties rely on outside income across size classes, but some insight can be had by looking at the average number of paid days worked on other farms, a signal of off-farm agricultural labor income (Fig. 14). Smaller properties appear increasingly reliant upon this source of income (20\% of properties smaller than 60 ha, compared with $3 \%$ of properties greater than 60 ha; the low number of properties engaging in labor prohibits a difference-of-means test), a diversification of effort into wage labor consistent with the HOT farm model developed above and supporting H3. 
Fig. 14. Average paid days worked on other farms. Percent refers to the percent of surveys in each size class used to generate bars; $\mathrm{n}_{\mathrm{JP}}, \mathrm{n}_{\mathrm{MA}}$, and $\mathrm{n}_{\mathrm{CA}}$ are the number of surveys used from each of Ji-Paraná, Machadinho, and Cacoal, respectively.

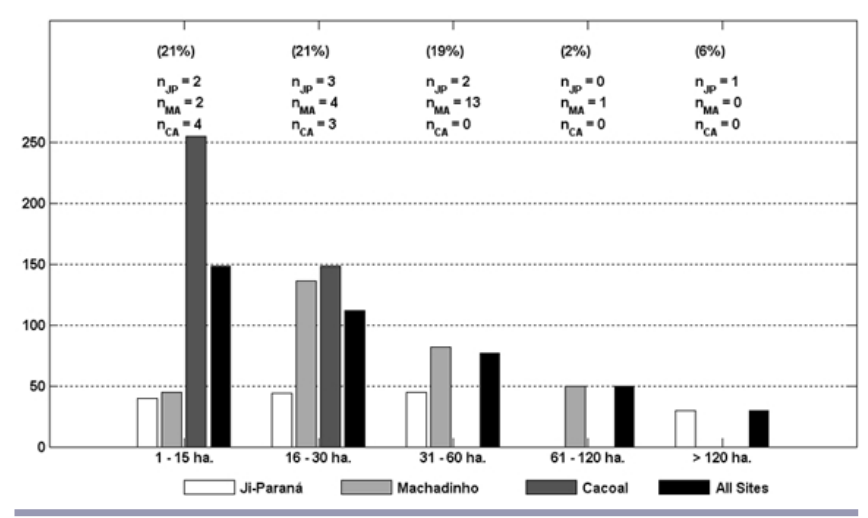

\section{Property division and aggregation}

Patterns in the exchange of land holdings can be important indicators of socioeconomic stratification in rural households (Browder et al. 2008). In the sample, the pattern of land consolidation suggests an archetypal 'success to the successful' behavior; the bigger the property, the more likely that it had augmented its holdings through land purchase (Fig. 15 ), with a significantly greater proportion of properties larger

Fig. 15. Proportion of properties in the sample having bought or sold land. Percent refers to the percent of surveys in each size class used to generate bars; $n$ is the number of surveys used.

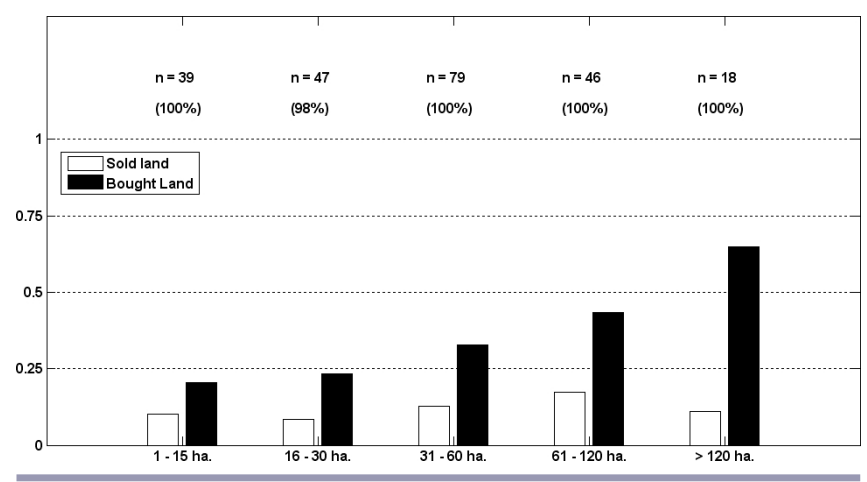

than 120 ha having purchased land than in all other size classes (Appendix 3). Of the 87 transactions for which the reason for purchase was given, the majority cites the expansion of cattle or crops $(66 \%)$ or a good opportunity for investment $(20 \%)$. A much smaller fraction cites the aid of family or neighbors $(10 \%)$ or structural reasons such as gaining access to water $(5 \%)$.
Looking to land sales, though the number of reported transactions is much lower (30 in total), there is far more variability in the reasons cited. Farmers cite the need to cover a debt or pay for care during an illness (27\%), the desire to invest in capital (27\%) or other land holdings (10\%), or the subdivision of properties within family due to inheritance or divorce (23\%). Many of these reasons reflect the usage of land as stored wealth, used to respond to needs that arise. The sale transactions are most interesting, however, as a crude signal of resilience and how farm fragility increases for smaller properties. The amount of land sold in these transactions, as a fraction of current land holdings, is much higher for smaller properties than for larger (Fig. 16).

Fig. 16. Land sold as a fraction of current holdings. The value $\mathrm{n}$ is the number of transactions that occurred in each size class.

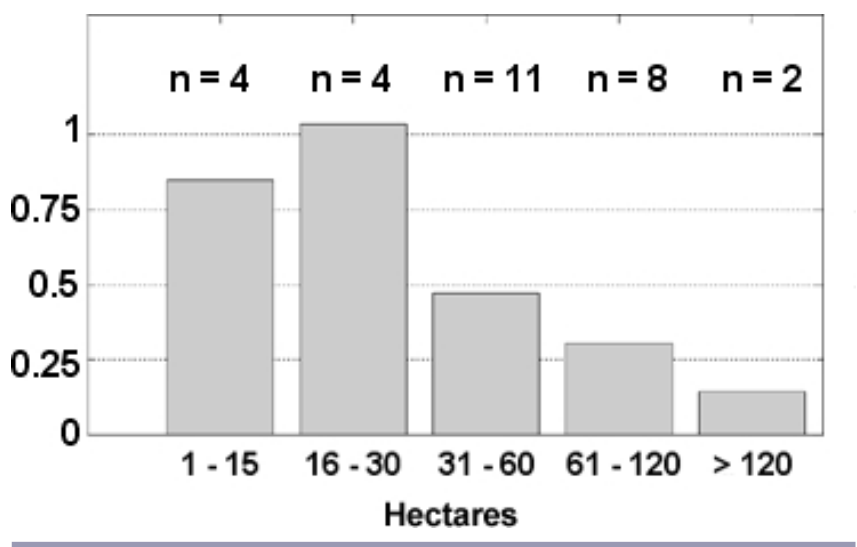

Although this might at first seem to be a trivial mathematical consequence of properties across scales selling similarly sized parcels, it is more a suggestion that households across the scale range of the study experience similar pressures, but that larger, more successful properties have the means to respond to these pressures without compromising as much of their means of farm production, of which land is a critical component. This result fits the prediction of the HOT farm model outlined above, and provides some support for $\mathrm{H} 2$ and $\mathrm{H} 4$, but the low number of transactions is statistically unsatisfying, and in fact, incomplete. Farmers selling off all of their property, rather than only a portion, would leave the sample frame and not be included in a study such as this. Data from the longitudinal study of Caviglia-Harris et al. (2009), which includes land transactions, better captures the households that leave the landscape, and provides an additional lens into this aspect of resilience. The Caviglia-Harris study reports relatively low attrition rates corresponding to about $1 \%$ per year between 1996 and 2000, rising to $2 \%$ between 2000 and 2005 (CavigliaHarris 2005, Caviglia-Harris et al. 2009; J. L. Caviglia-Harris, E. O. Sills, and K. Mullan, unpublished manuscript). However, breaking these data down by size class, $29 \%$ of 
households on farms smaller than 30 ha had left the frame by 2000 , compared with less than $10 \%$ of larger properties; by 2009 , these numbers had risen to $42 \%$ and $33 \%$, respectively (J. L. Caviglia-Harris, personal communication).

\section{IMPLICATIONS OF HOT FARMS}

The empirical results shown here provide some support for the HOT farm model. Smaller properties make more intensive use of both their land and their time, producing more per hectare from a more diversified array of crops and livestock, and investing more of their time in wage labor than larger properties. There is also some evidence that the small farms are more fragile, i.e., closer to a HOT state, than larger properties. A longitudinal study would provide more evidence, but the data presented on the purchase and sale of land demonstrate similar land sales to respond to stresses across size classes, corresponding to significantly higher compromising of the means of production for smaller properties. These results are promising indicators of the value of the concept of HOT to explain the shifts in capacity and resilience across scale on family farms, and inform research and decisions related to improving social and environmental conditions in agricultural landscapes.

\section{So what? The case of environmental licensing}

One area where the treatment of farms as HOT systems is of particular and current relevance is in the design of public policy in Rondônia, where at the time of writing there is legislative debate about how to implement a plan for environmental licensing on rural properties (LAPRO; SEDAM-RO 2008). LAPRO will require farms to maintain half of their lands in what is called 'legal reserve' (LR) forest, in addition to maintaining forest cover along all water courses and steep hillslopes in 'areas of permanent preservation' (APP; Brazilian Forest Code 1965). Although the Brazilian Forest Code has required this since 1965 , the historical need to stake claim to land by clearing it and by demonstrating intention to use it productively provided a clear incentive to deforest (Hecht and Cockburn 1989, Fearnside 2001, Caldas et al. 2007), making LAPRO seem very much a reversal by the state.

To obtain a license, properties must demonstrate a management plan to bring their properties in line with the requirements of the Forest Code within a period of 30 years; these include maintenance of APP and an area equivalent to $50 \%$ of the property in LR for properties that were deforested as of 2005; only $20 \%$ of property not cleared prior to 2005 may be cleared under LAPRO. At present, this license is in theory required for properties to access any form of rural credit. In the future, SEDAM-RO hopes to make licenses a requirement for farmers to access markets for their products.

For many smaller properties, this will mean a huge cut in income essential to meeting basic household needs. To lessen the burden that LAPRO might place on smaller farms, proposals have been put forward by several organizations in the state to change the requirements of the program. One proposal suggests amnesty for all deforestation prior to 2008 and an exemption for properties up to four fiscal modules (one fiscal module $=60$ ha for Rondônia) of the obligation to maintain LR (Mudanças Climáticas 2010); another suggests a tiered structure for family farms that scales up the LR requirements from nothing for farms under one fiscal module up to $50 \%$ for farms greater than two fiscal modules (de Jesus 2009). Any decision here will involve balancing among the needs of small farms, larger farms, and the environment, making an understanding of the way small farms perform, and their capacity to remain viable with substantial portions of land taken out of production, extremely important.

The results of this study demonstrate a marked difference in farm characteristics between farms smaller than 60 ha and farms larger than 60 ha. Smaller farms commit more land to annuals and perennials, use agricultural inputs more intensively, and spend more per hectare on maintenance and labor. Cattle are herded more densely and production is markedly higher and more diverse. These clear differences warrant more in-depth study of the way in which properties at different scales will be differentially affected by LAPRO, and how the proposed modifications may alter these as well as the land cover outcomes that are the goals of the program. Some work investigating the potential for smaller ranchers to remain viable under LAPRO has been undertaken using an agentbased simulation of the Rondonian ranching landscape (Bell 2011). A concern is that for some smaller properties, removing significant land from use may make the property unviable, and drive these households from the agricultural landscape. Although the 'extended urbanization' of the Rondonian postfrontier (Monte-Mór 2004) offers many opportunities outside of agriculture, some of which may soon expand through the Growth Acceleration Program (PAC) and the development along the length of the BR-364 highway that is accompanying the building of hydroelectric dams along the Madeira River, it is irresponsible to expect these labor markets to be sinks for farmers unable to compete under LAPRO. Analysis of LAPRO favoring the extension of land use restrictions to small farms should demonstrate the capacity of local labor markets to absorb increased need among farmers for wage or professional labor. Without such assurance, the attempt to improve the system with a policy intervention may in fact "undermine its ability to cope with change and maintain its structure and function" (Janssen et al. 2007:310), with the environmental goal of maintaining forest cover coming into conflict with the original social goal of generating livelihoods through colonization.

\section{RESPONSES TO THIS ARTICLE}

Responses to this article are invited. If accepted for publication, your response will be hyperlinked to the article. 
To submit a response, follow this link. To read responses already accepted, follow this link.

\section{ACKNOWLEDGMENTS}

I gratefully acknowledge Jill Caviglia-Harris for providing data and valuable comments on changes in land holdings. This study was funded by grants from the Graham Environmental Sustainability Institute and the Rackham Graduate School, both at the University of Michigan and the Earth Institute at Columbia University. The questionnaire developed for this study drew from material previously developed by the ACT Institute at Indiana University. Initial support in project planning and development was provided by Tatiane Checchia and Paulo Schröder at the Amazônian Protection System (SIPAM). Logistic support in the administration of questionnaires was provided by the agency for technical assistance and rural extension for Rondônia, EMATER-RO. Finally, the author is grateful for assistance in project coordination from Dr. Margarida Marchetto of the Federal University of Rondônia (UNIR) and for the hard work of the research team - Thiago Emanuel Figueiredo Possmoser Nascimento, Ingrid Alexandrina Martins Veronez, Emerson Andrade de Souza, Mônica Chagas Cerquiera, João Paulo Papaleo Costa Moreira, Carina Stre Holanda, and Leonardo Rosa Andrade - from the Department of Environmental Engineering at UNIR Ji-Paraná.

\section{LITERATURE CITED}

Allison, P. D. 1978. Measures of inequality. American Sociological Review 43:865-880.

Bailey, K. D. 1983. Sociological entropy theory - toward a statistical and verbal congruence. Quality \& Quantity 18:113-133.

Bell, A. R. 2011. Environmental licensing and land aggregation: an agent-based approach to understanding ranching and land use in rural Rondônia. Ecology and Society 16(1): 31. [online] URL: http://www.ecologyandsociety.org/v ol16/iss $1 /$ art $31 /$.

Brazilian Forest Code. 1965. Código Florestal (Law 4771).

Browder, J. O., and M. A. Pedlowski. 2000. Agroforestry performance on small farms in Amazonia: findings from the Rondonia agroforestry pilot project. Agroforestry Systems 49:63-83.

Browder, J. O., M. A. Pedlowski, R. Walker, R. H. Wynne, P. M. Summers, A. Abad, N. Becerra-Cordoba, and J. MilHomens. 2008. Revisiting theories of frontier expansion in the Brazilian Amazon: a survey of the colonist farming population in Rondonia's post-frontier, 1992-2002. World Development 36:1469-1492.

Browder, J. O., R. H. Wynne, and M. A. Pedlowski. 2005. Agroforestry diffusion and secondary forest regeneration in the Brazilian Amazon: further findings from the Rondonia Agroforestry Pilot Project (1992-2002). Agroforestry Systems 65:99-111.

Caldas, M., R. Walker, E. Arima, S. Perz, S. Aldrich, and C. Simmons. 2007. Theorizing land cover and land use change: the peasant economy of Amazonian deforestation. Annals of the Association of American Geographers 97:86-110.

Carlson, J. M., and J. Doyle. 1999. Highly optimized tolerance: robustness and design in complex systems. Physical Review Letters 84:2529-2532.

Caviglia-Harris, J. L. 2005. Cattle accumulation and land use intensification by households in the Brazilian Amazon. Agricultural and Resource Economics Review 34:145-162.

Caviglia-Harris, J. L., E. O. Sills, L. Jones, S. Saha, D. Harris, S. McArdle, D. Roberts, M. A. Pedlowski, and R. Powell. 2009. Modeling land use and land cover change in an Amazonian frontier settlement: strategies for addressing population change and panel attrition. Journal of Land Use Science 4:275-307.

D'Antona, A. O., L. K. VanWey, and C. M. Hayashi. 2006. Property size and land cover change in the Brazilian amazon. Population and Environment 27:373-396.

de Jesus, A. 2009. Altera e acresce dispositivos à Lei $n^{\circ} 4.771$, de 15 de setembro de 1965, Código Florestal Brasileiro. PL 5020/2009 Brasília, Brasil. [online] URL: http://www.camara. gov.br/sileg/Prop Detalhe.asp?id=429594.

Ellis, F. 1993. Peasant economics: farm households and agrarian development. Cambridge University Press, Cambridge, UK.

EMBRAPA. 2009. Sustentabilidade Agrícola na Amazônia Machadinho d'Oeste - Embrapa Monitoramento por Satélite. Ministério da Agricultura, Brasília, Brasil. [online] URL: htt p://www.machadinho.cnpm.embrapa.br/conteudo/historico.htm

Faminow, M. D. 1998. Cattle, deforestation and development in the Amazon: an economic, agronomic and environmental perspective. Center for Agriculture and Biosciences International, New York, New York, USA.

Fearnside, P. M. 2001. Land-tenure issues as factors in environmental destruction in Brazilian Amazonia: the case of Southern Para. World Development 29:1361-1372.

Galtung, J. 1980. The true worlds: a transnational perspective. Free Press, New York, New York, USA.

Gill, J. 2005. An entropy measure of uncertainty in vote choice. Electoral Studies 24:371-392.

Hecht, S., and A. Cockburn. 1989. The fate of the forest. Verso, London, UK. 
Instituto Brasileiro de Geografia e Estatística (IBGE). 1996. Censo Agropecuário de 1995-1996. Ministério do Planejamento, Or\&\#231amento e Gestão, Brasília, Brasil. [online] URL: http://www.ibge.gov.br/home/estatistica/economia/ agropecuaria/censoagro/1995 1996/11/d11 t10.shtm.

Instituto Nacional de Colonização e Reforma Agrária (INCRA). 1998. Realidade Migratória em Rondônia - década de 90 e Perspectivas. INCRA, Ministério do Desenvolvimento Agrário, Brasília, Brasil.

Janssen, M. A., J. M. Anderies, and E. Ostrom. 2007. Robustness of social-ecological systems to spatial and temporal variability. Society \& Natural Resources 20:307-322.

Kaufman, S., E. Kwon, N. Krishnan, M. Castaldi, and N. Themelis. 2008. Use of statistical entropy and life cycle analysis to evaluate global warming potential of waste management systems. 16th Annual North American Waster to Energy Conference NAWTEC 16:107-112.

Monte-Mór, R. L. 2004. Modernities in the jungle: extended urbanization in the Brazilian Amazon. Dissertation. University of California, Los Angeles, California, USA.

Muchagata, M., and K. Brown. 2003. Cows, colonists and trees: rethinking cattle and environmental degradation in Brazilian Amazonia. Agricultural Systems 76:797-816.

Mudanças Climáticas. 2010. Mudança no Código Florestal recebe críticas da Casa Civil. Agência de Notícias dos Direitos da Infância (ANDI) with support from the British Council, Brazil. [online] URL: http://www.mudancasclimaticas.andi.org. br/node/1493/.

Rechberger, H. 2001. The use of statistical entropy to evaluate the utilisation of incinerator ashes for the production of cement. Waste Management \& Research 19:262-268.

Rechberger, H., and T. E. Graedel. 2002. The contemporary European copper cycle: statistical entropy analysis. Ecological Economics 42:59-72.

Scheffer, M., W. Brock, and F. Westley. 2000. Socioeconomic mechanisms preventing optimum use of ecosystem services: an interdisciplinary theoretical analysis. Ecosystems 3:451-471.

Schmink, M., and C. Wood. 1992. Contested frontiers in Amazonia. Columbia University Press, New York, New York, USA.

Secretaria de Estado de Desenvolvimento Ambiental (SEDAM-RO). 2008. Manual operacional para a licença ambiental em propriedade rural no estado de Rondônia. Secretaria de Estado de Desenvolvimento Ambiental, Porto Velho, Brasil.
Shuiabi, E., V. Thomson, and N. Bhuiyan. 2005. Entropy as a measure of operational flexibility. European Journal of Operational Research 165:696-707.

Sills, E. O., and J. L. Caviglia-Harris. 2008. Evolution of the Amazonian frontier: land values in Rondônia, Brazil. Land Use Policy 26:55-67.

Torquebiau, E., and E. Penot. 2006. Ecology versus economics in tropical multistrata agroforests. Pages 269-282 in B. M. Kumar and P. K. R. Nair, editors. Tropical homegardens: a time-tested example of sustainable agroforestry. Springer, Dordrecht, The Netherlands.

Walker, B., C. S. Holling, S. R. Carpenter, and A. Kinzig. 2004. Resilience, adaptability and transformability in socialecological systems. Ecology and Society 9(2): 5. [online] URL: http://www.ecologyandsociety.org/vol9/iss2/art5/.

Walker, R., E. F. Moran, and L. Anselin. 2000. Deforestation and cattle ranching in the Brazilian Amazon: external capital and household processes. World Development 28:683-699.

Walker, R., S. Perz, M. Caldas, and L. G. H. Silva. 2002. Land use and land cover change in forest frontiers: the role of household life cycles. International Regional Science Review 25:169-199. 


\section{Appendix 1}

\section{Mathematics of Diversification}

Consider a farmer's decision to allocate effort $\mathrm{X}$ among a set of revenue-generating activities such that $\mathrm{x}_{\mathrm{i}}$ represents the effort allocated to activity $i$. Each activity $i$ is defined by 1 ) the expected net return per unit effort $E_{i}=R_{i}$, where $R_{i}$ is the per-unit revenue and $C_{i}$ is the per-unit cost; 2) $f_{i}$, a scaling factor on $E_{i}$ whose variability reflects the effect of disturbance on expected net revenue; as an example, for the cultivation of rice as an activity, a drought might give an $\mathrm{f}<$ 1, while exceptional growth conditions might give an $\mathrm{f}>1$; and 3 ) $\mathrm{I}_{\mathrm{i}}$, a fixed investment cost, or transaction cost, for allocating effort in activity $i$. The farmer's profit is given then by:

$$
P=\sum_{i}\left(E_{i} f_{i} x_{i}-I_{i}\right)
$$

By inspection, it is clear that $\mathrm{dP} / \mathrm{dx}_{\mathrm{i}} \sim \mathrm{E}_{\mathrm{i}}$, and thus to maximize profits the farmer allocates effort in activities where $E$ is high and $I$ is not prohibitive. In contrast, $\mathrm{dP} / \mathrm{df}_{\mathrm{i}} \sim 1 / \mathrm{x}_{\mathrm{i}}$ and is reduced when variability in $f_{i}$ is low, or when effort is spread across activities where values of $f$ are not expected to co-vary, keeping $\mathrm{x}_{\mathrm{i}}$ in individual activities $i$ low.

These objectives of profit maximization and risk minimization may thus be at odds with one another, and it is worthwhile to consider the case of a farmer diverting efforts from an existing set of activities into a new activity $j$. Consider the case where the farmer diversifies effort into a new activity $j$. The change in profit $\mathrm{P}$ is given by:

$$
\frac{d P}{d x_{j}}=E_{j} f_{j} d x_{j}-I_{j}-\sum_{i \neq j}\left(E_{i} f_{i} d x_{i}\right)
$$

For simplicity, we assume that allocation away from any activity $i$ does not lead to the return of the investment cost $\mathrm{I}_{\mathrm{i}}$. If the change in profit is to be positive, it must be that: 


$$
\begin{aligned}
0 & <E_{j} f_{j} d x_{j}-I_{j}-\sum_{i \neq j}\left(E_{i} f_{i} d x_{i}\right) \\
I_{j}+\sum_{i \neq j}\left(E_{i} f_{i} d x_{i}\right) & <E_{j} f_{j} d x_{j} \\
\frac{I_{j}}{d x_{j}}+\frac{\sum_{i \neq j}\left(E_{i} f_{i} d x_{i}\right)}{d x_{j}} & <E_{j} f_{j}
\end{aligned}
$$

Noting that effort reallocated to $j, \mathrm{dx}_{\mathrm{j}}$, is simply the sum of effort taken away from other activities $i$, we obtain:

$$
\frac{I_{j}}{d x_{j}}+E f_{\text {avg }, i \neq j}<E_{j} f_{j}
$$

Simply put, if diversifying into $j$ is to increase profit, then the expected return on effort (given stressor $\mathrm{f}_{\mathrm{j}}$ ) must be greater than the average expected return on all other activities (given stressors 1 to $i$ ) plus the 'per-unit' investment cost to enter into activity $j$ given our allocated effort $\mathrm{x}_{\mathrm{j}}$. If we assume that within a set of activities where $\mathrm{I}_{\mathrm{i}}$ is not prohibitive to enter, the farmer will invest initially in those activities with higher $\mathrm{E}_{\mathrm{i}}$, it is reasonable to expect that $\mathrm{E}_{\mathrm{j}}$ for the new activity $j$ will be lower. Thus, $E_{j} f_{j}$ will not in general be greater unless $f_{j}$ is much larger than $f_{1}, f_{2} \ldots, f_{j}$; in general diversifying effort in order to reduce risk to fluctuations in $f_{i}$ will lead to a reduction in profit.

The term $\mathrm{I}_{\mathrm{j}} / \mathrm{dx}_{\mathrm{j}}$ means that, when initial investment costs are higher, the activity requires allocation of more effort in order to be more 'worthwhile,' making diversification a lumpy process, and making many activities with high $\mathrm{I}_{i}$ prohibitive unless $\mathrm{E}_{\mathrm{i}}$ is particularly high or variability in $f_{i}$ particularly low. In cases where the initial investment $I_{j}$ is high - such as the search for wage labor in a weak labor market, or investment in capital-intensive activities such as cattle or dairy - an unexpected downshift in $f_{j}$ can leave the farmer significantly worse off than if effort had not been allocated to $j$ at all. The factors $f_{i}$ can reflect many different aspects of climate, markets, and other stressors, and many may co-vary significantly; as such, it is nontrivial for the farmer to estimate whether the lumpy investment of effort into activity $j$ is worthwhile or not.

In general, profit maximization involves investing in a smaller number of activities where $\mathrm{E}_{\mathrm{i}}$ is high, and $\mathrm{I}_{\mathrm{i}}$ is low. On the other hand, risk minimization involves investing in activities where variability in $\mathrm{f}_{\mathrm{i}}$ is low, and spreading effort across activities where variabilities in $\mathrm{f}_{\mathrm{i}}$ are not expected to co-vary. Given that in general $f_{i}$ are not perfectly known, and that the investment costs $\mathrm{I}_{\mathrm{i}}$ make diversification a lumpy endeavor, it is not trivial for the farmer (with some level of risk aversion) to decide where between these two extremes would be best. Given uncertainties in $f_{i}$, it is not obvious whether greater specialization or greater diversification will leave the farmer better off overall. 


\section{Appendix 2}

\section{Tabulated Size Class Mean Values and Proportions for Study Variables}

Tabulated results begin in landscape layout on the following page. 


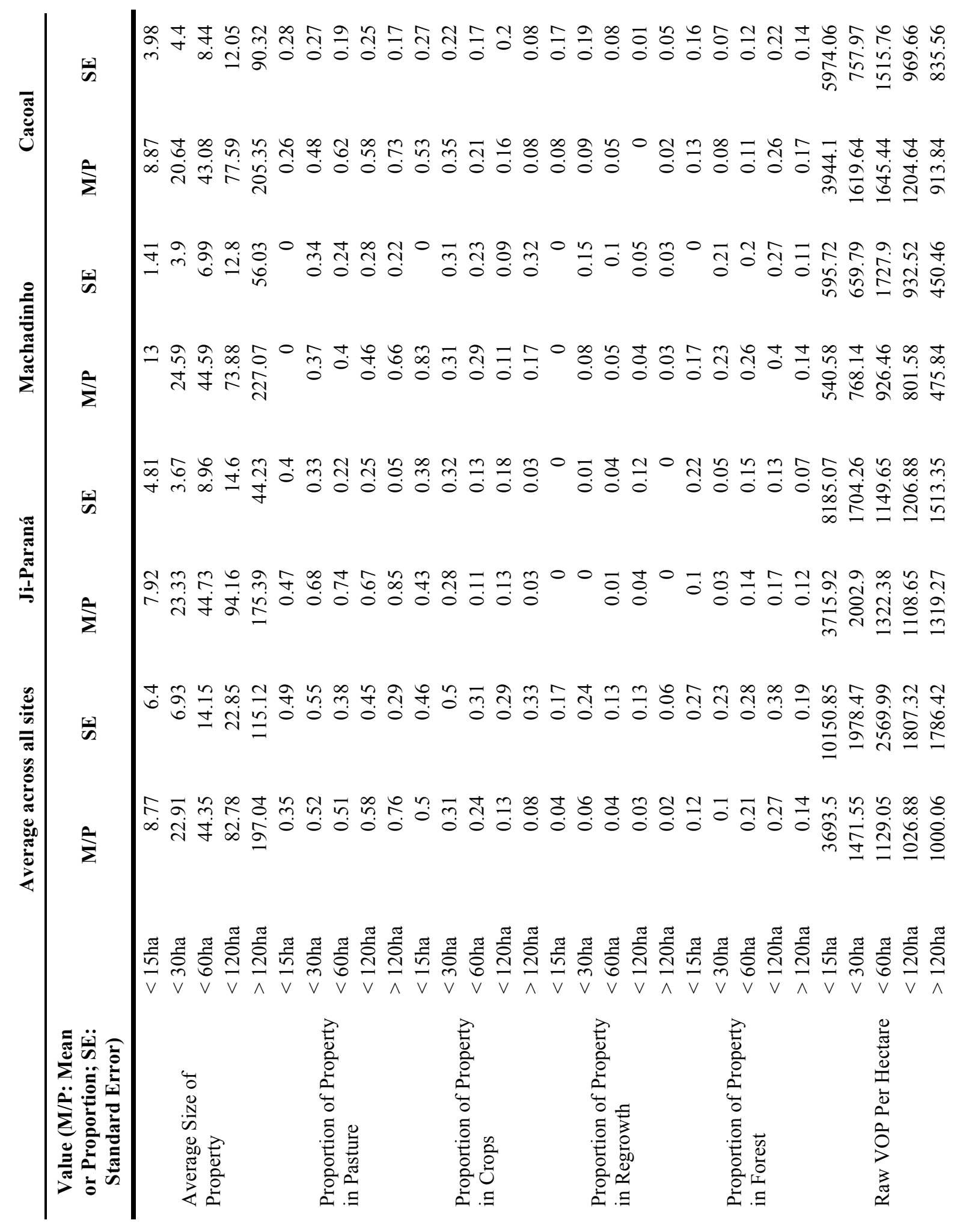




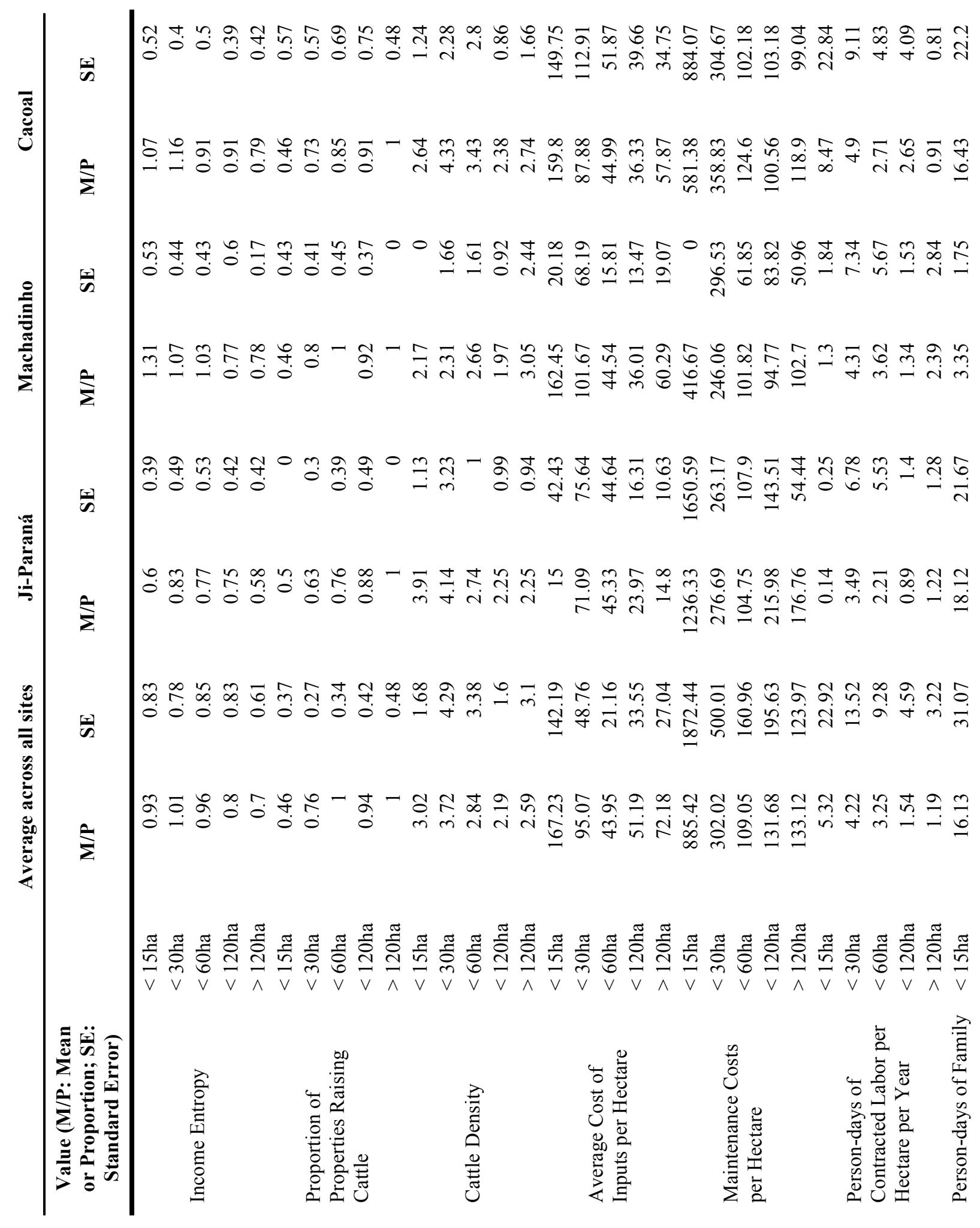




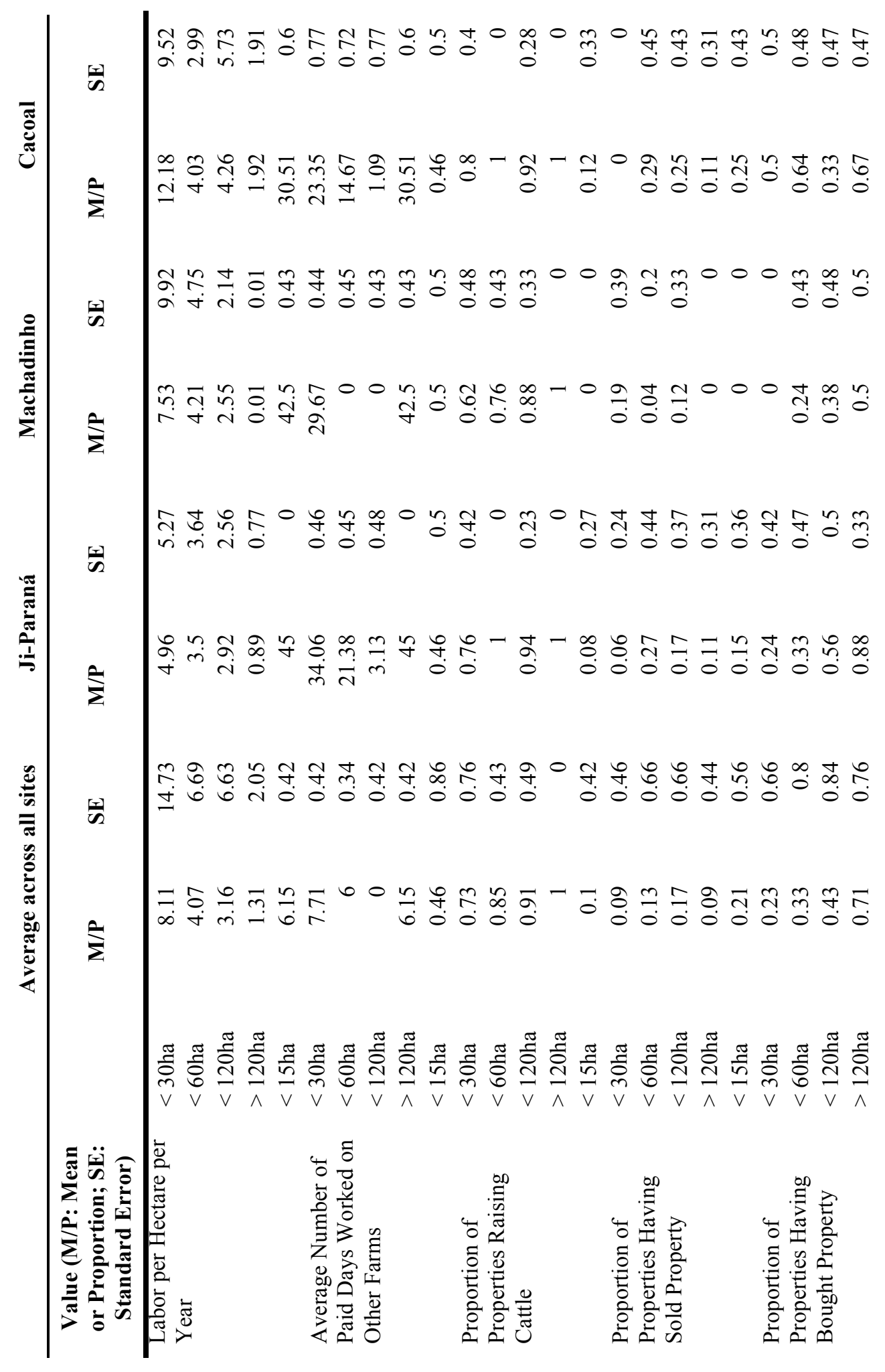




\section{Appendix 3}

\section{Difference of Means Test Results}

This appendix presents the p-values for differences between means and proportions for each size class in each question used in this analysis. Results begin on the following page. The p-value for the difference between each of the 10 different pairs of the 5 unique size classes is presented as an upper-triangular matrix for each of the Ji-Paraná, Machadinho, and Cacoal sites, as well as for the mean across all sites.

Differences significant at $90 \%$ confidence are marked in boldface and enclosed in gray. A value of ' $\mathrm{NaN}$ ' indicates a lack of any qualifying data points for analysis. 


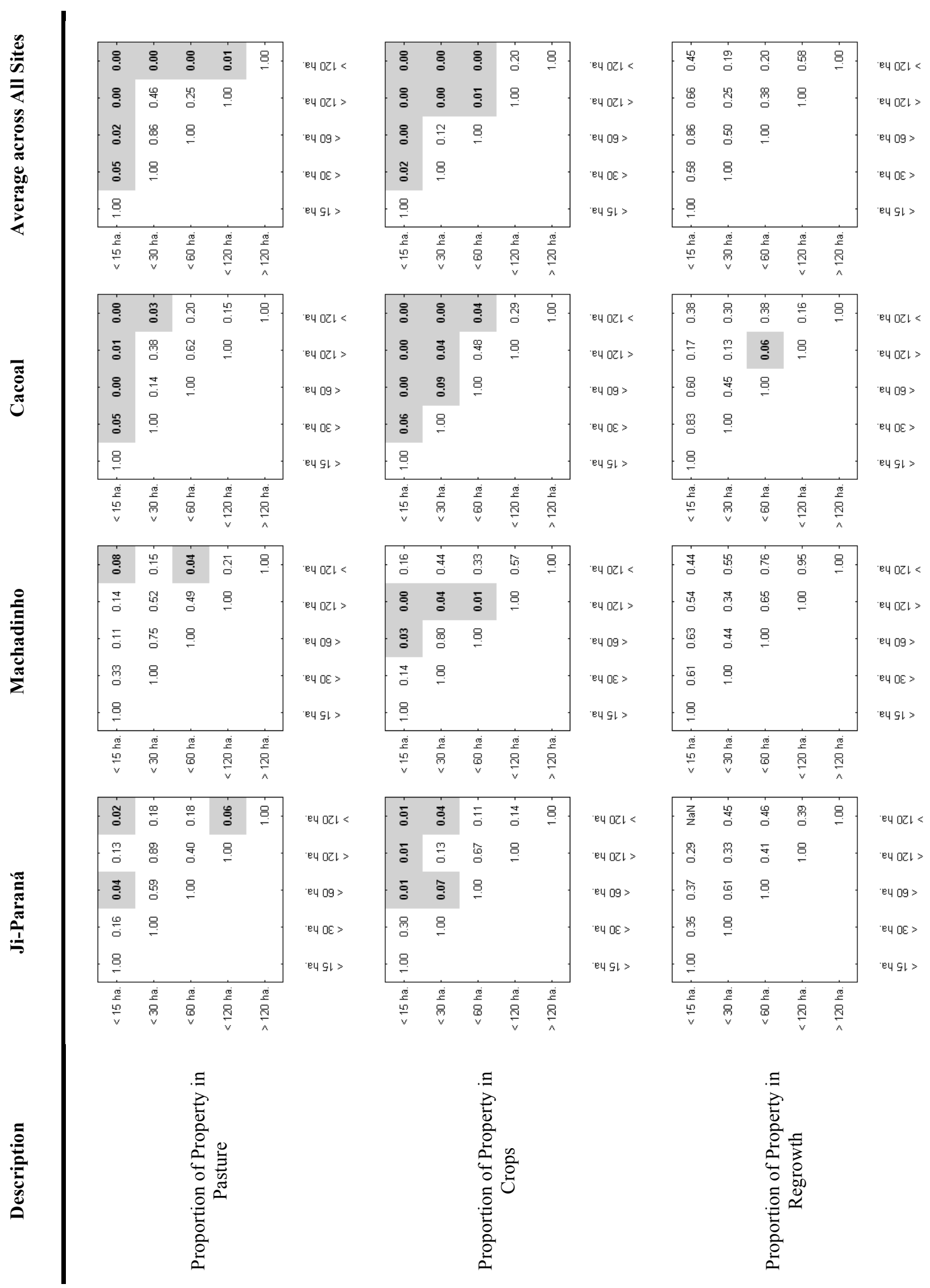




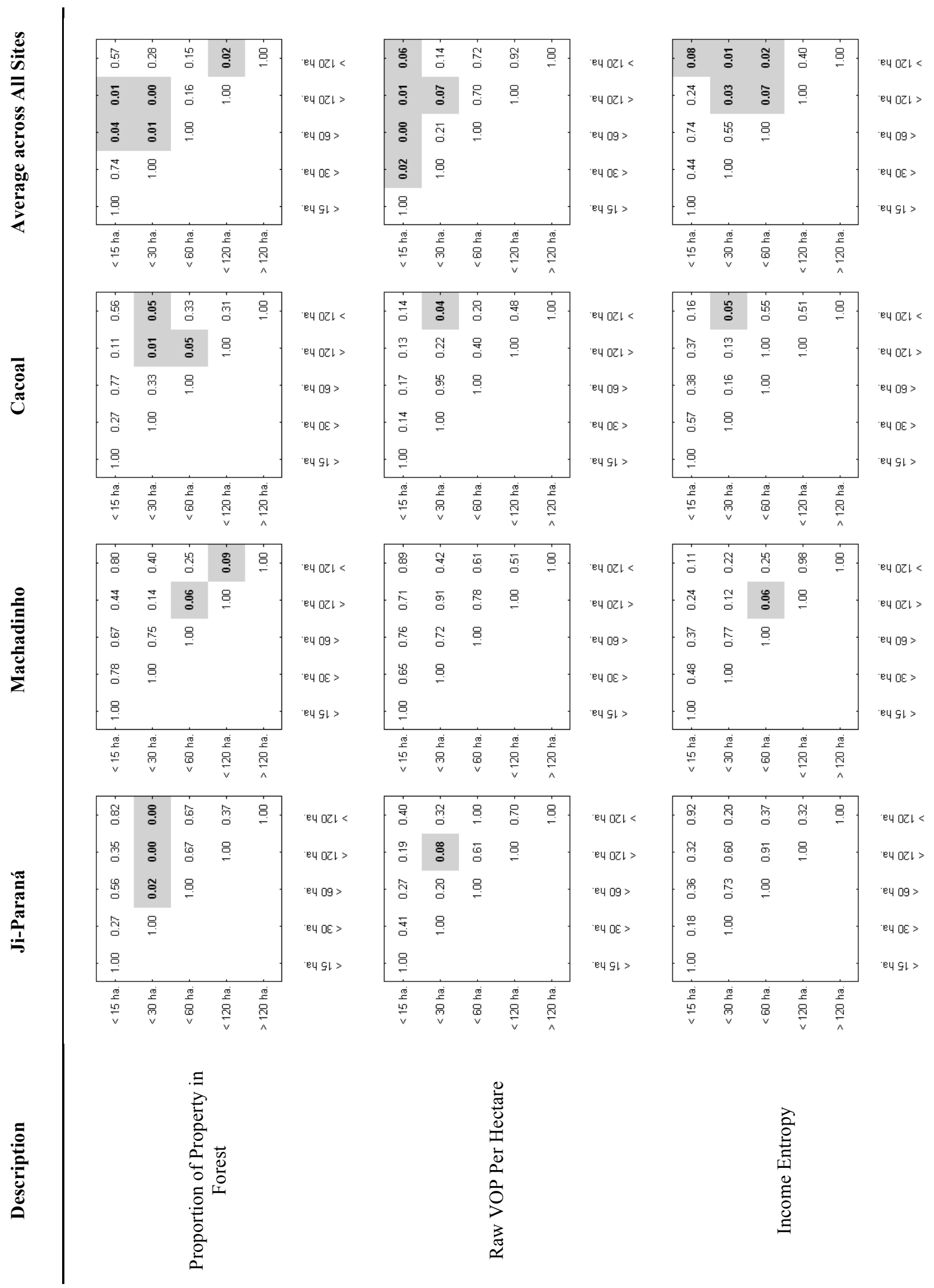




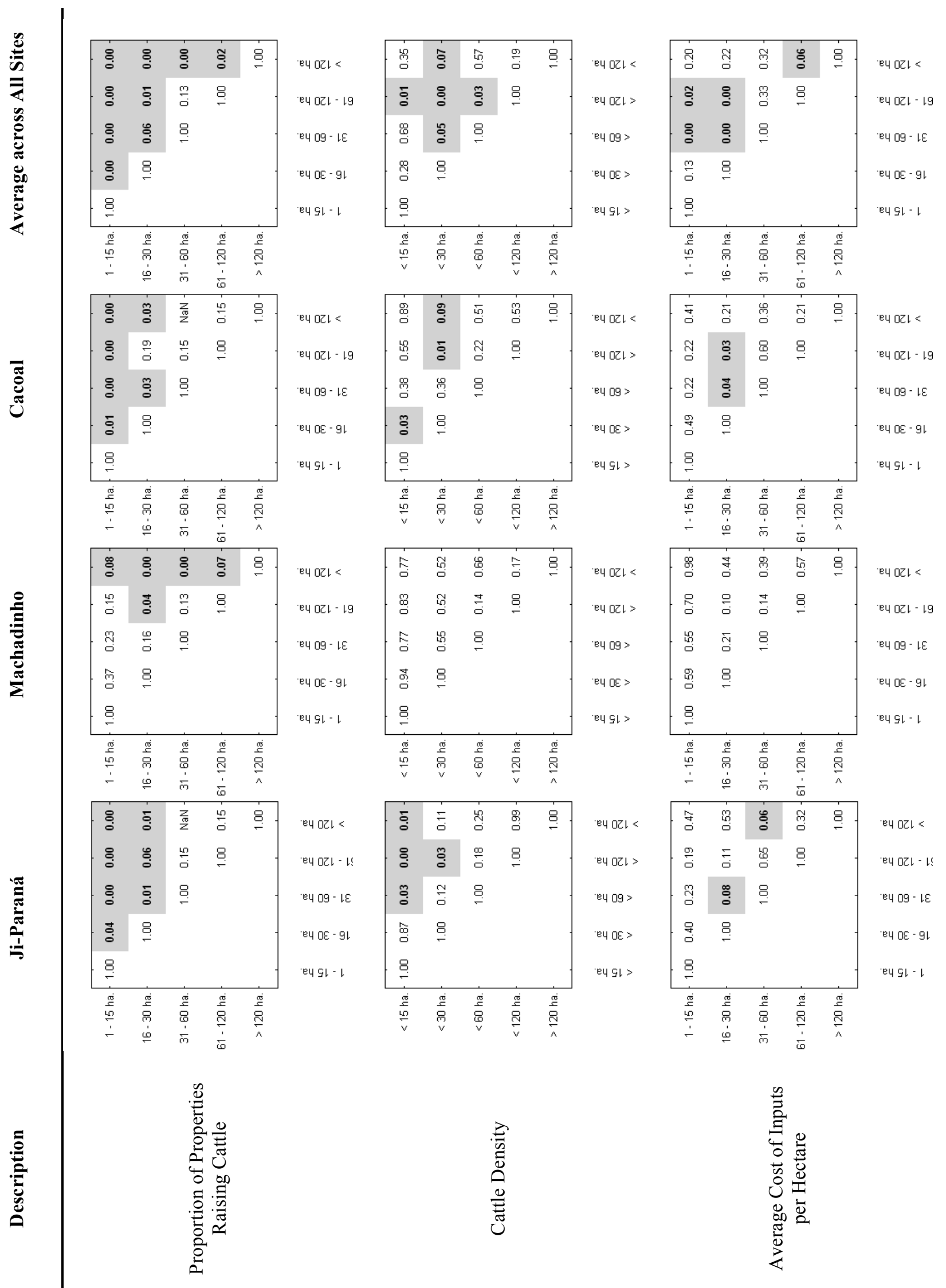




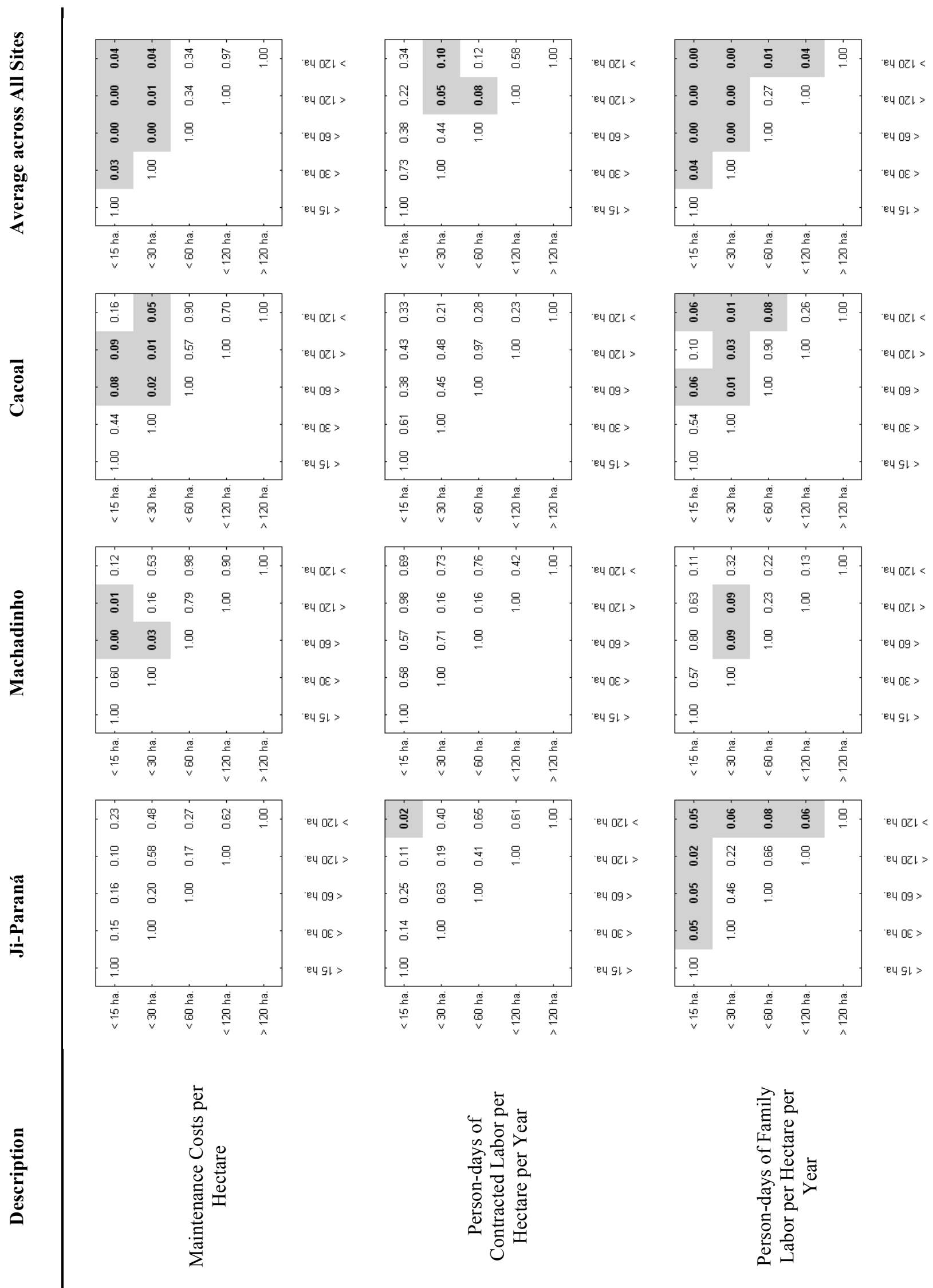




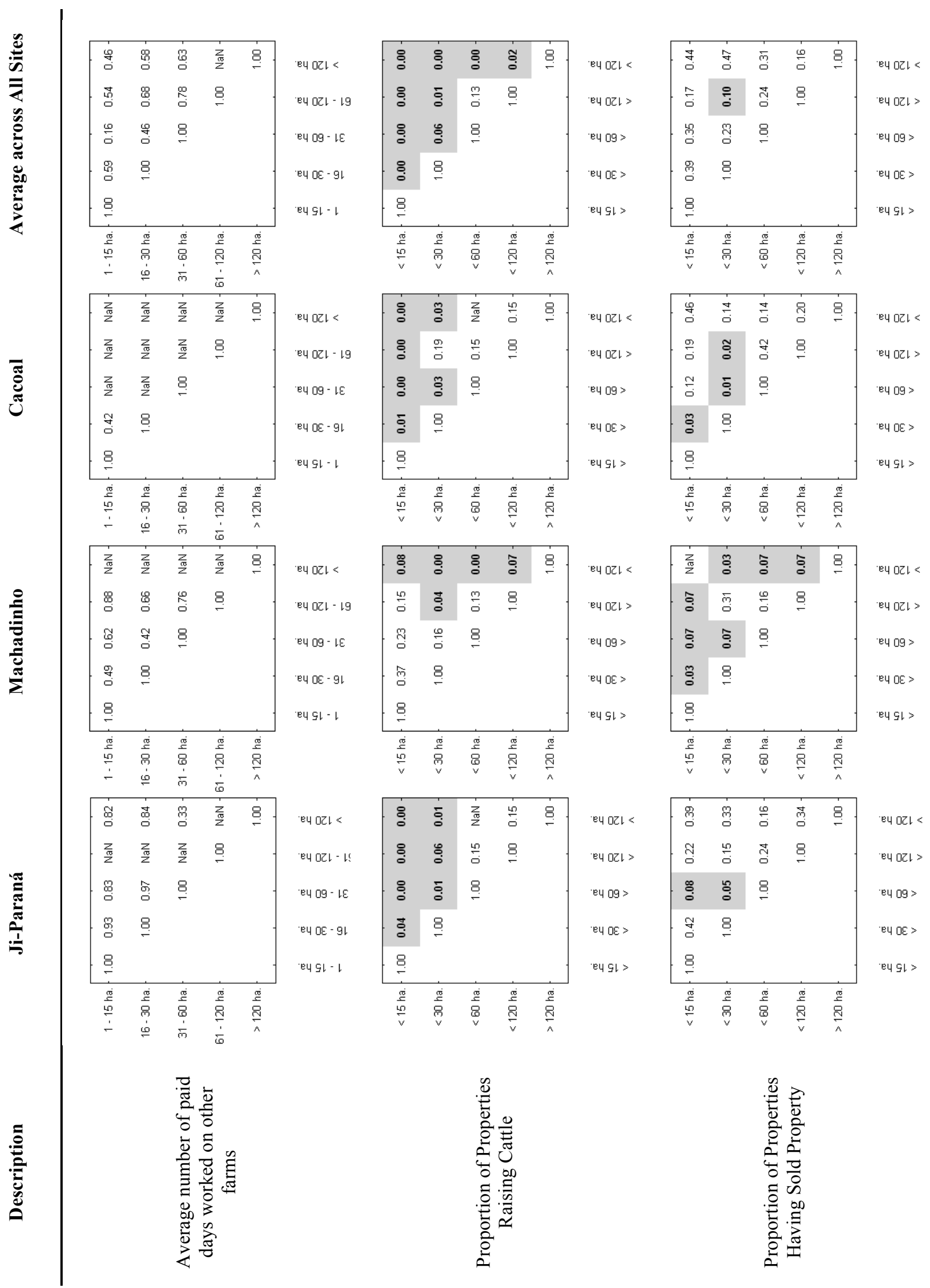




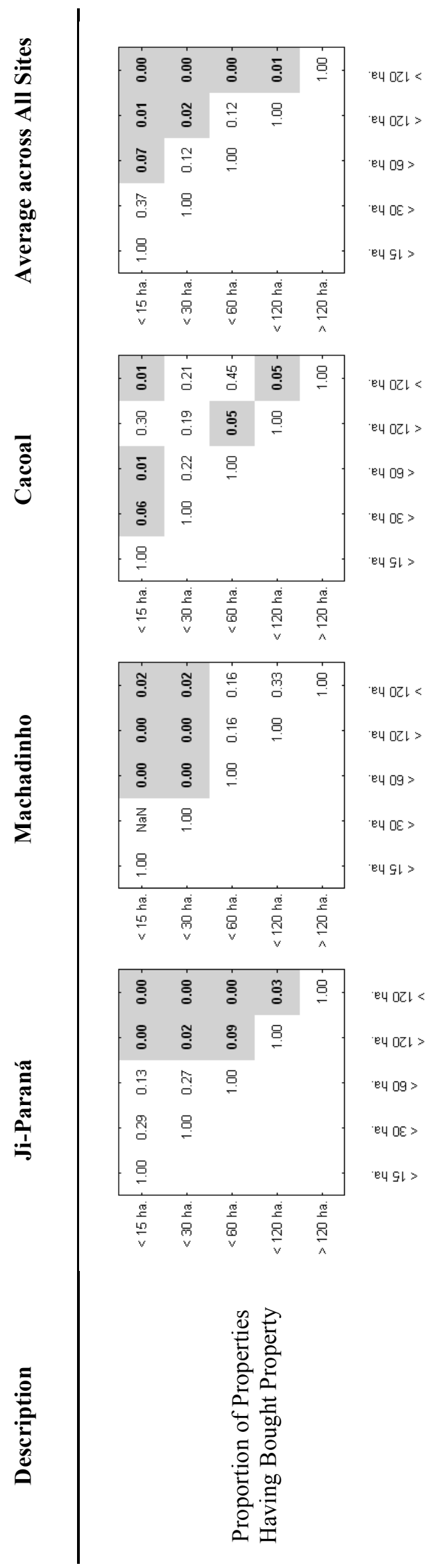




\section{Appendix 4}

\section{Supplemental Figures}

This appendix presents additional results that further clarify trends cited in the main manuscript, but are not integral to the central argument. 
Family labor - Pasture (Person-days/ha/y)

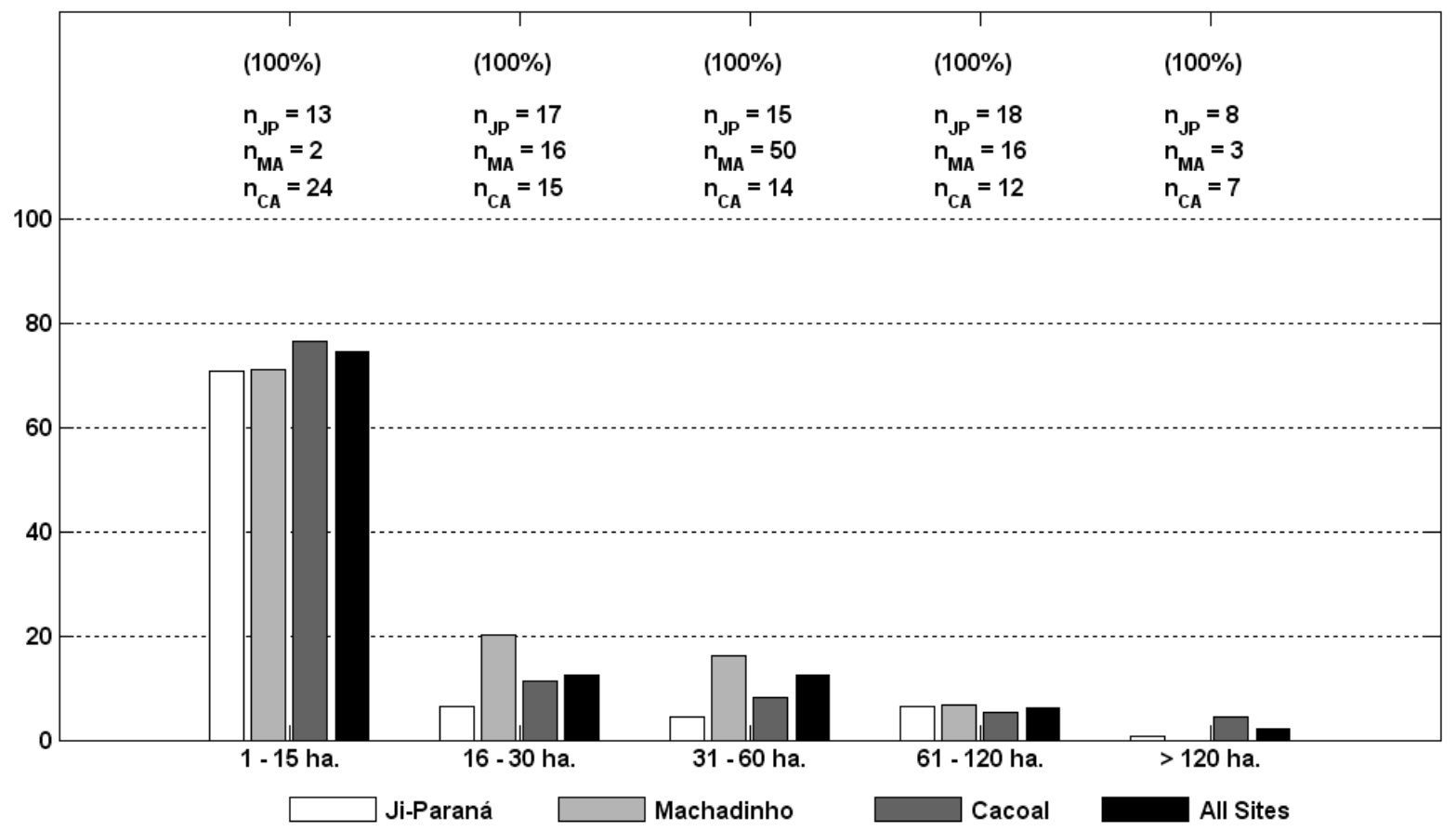

Figure A4.1: Family labor use for pasture. Percent refers to the percent of surveys in each size class used to generate bars; $\mathbf{n}_{\mathrm{JP}}, \mathbf{n}_{\mathrm{MA}}$, and $\mathbf{n}_{\mathrm{CA}}$ are the number of surveys used from each of Ji-Paraná, Machadinho, and Cacoal, respectively.

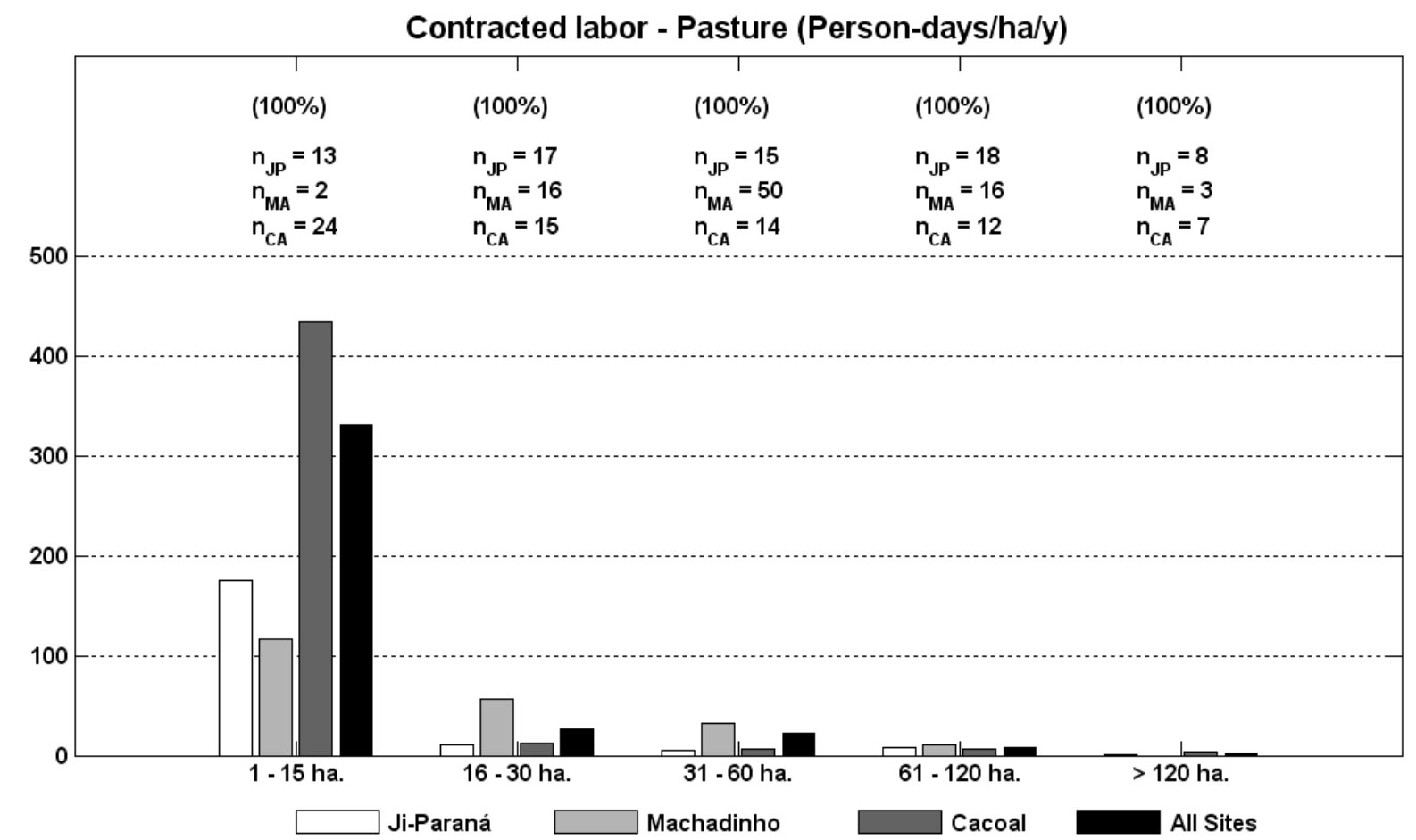

Figure A4.2: Contracted labor use for pasture. Percent refers to the percent of surveys in each size class used to generate bars; $\mathbf{n}_{\mathrm{JP}}, \mathbf{n}_{\mathrm{MA}}$, and $\mathbf{n}_{\mathrm{CA}}$ are the number of surveys used from each of Ji-Paraná, Machadinho, and Cacoal, respectively. 


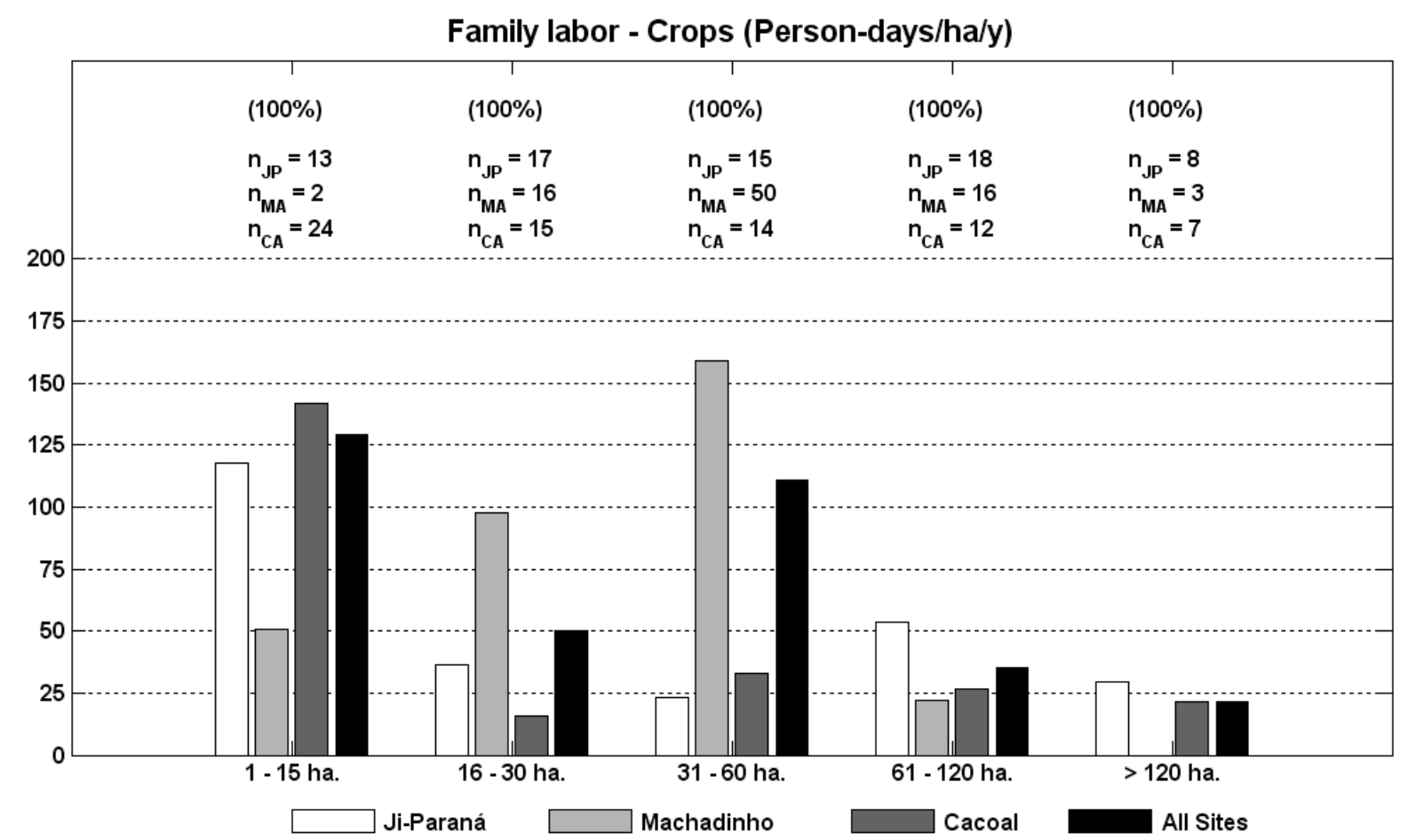

Figure A4.3: Family labor use for cropland. Percent refers to the percent of surveys in each size class used to generate bars; $\mathbf{n}_{\mathrm{JP}}, \mathbf{n}_{\mathrm{MA}}$, and $\mathbf{n}_{\mathrm{CA}}$ are the number of surveys used from each of Ji-Paraná, Machadinho, and Cacoal, respectively.

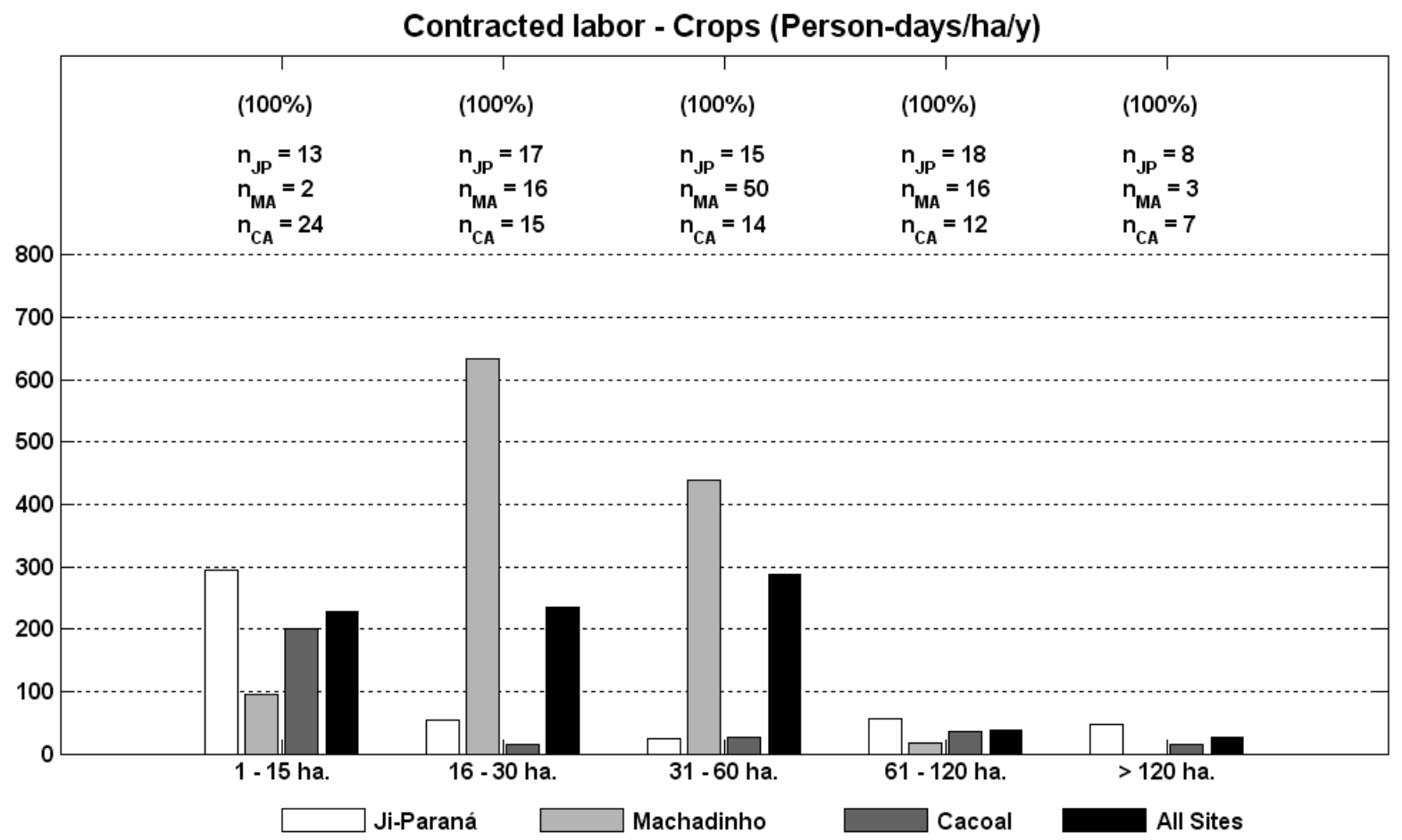

Figure A4.4: Contracted labor for cropland. Percent refers to the percent of surveys in each size class used to generate bars; $\mathbf{n}_{\mathrm{JP}}, \mathbf{n}_{\mathrm{MA}}$, and $\mathbf{n}_{\mathrm{CA}}$ are the number of surveys used from each of Ji-Paraná, Machadinho, and Cacoal, respectively. 
Input Intensity (Fertilizer and Insecticide only) (\$R/ha cropland)

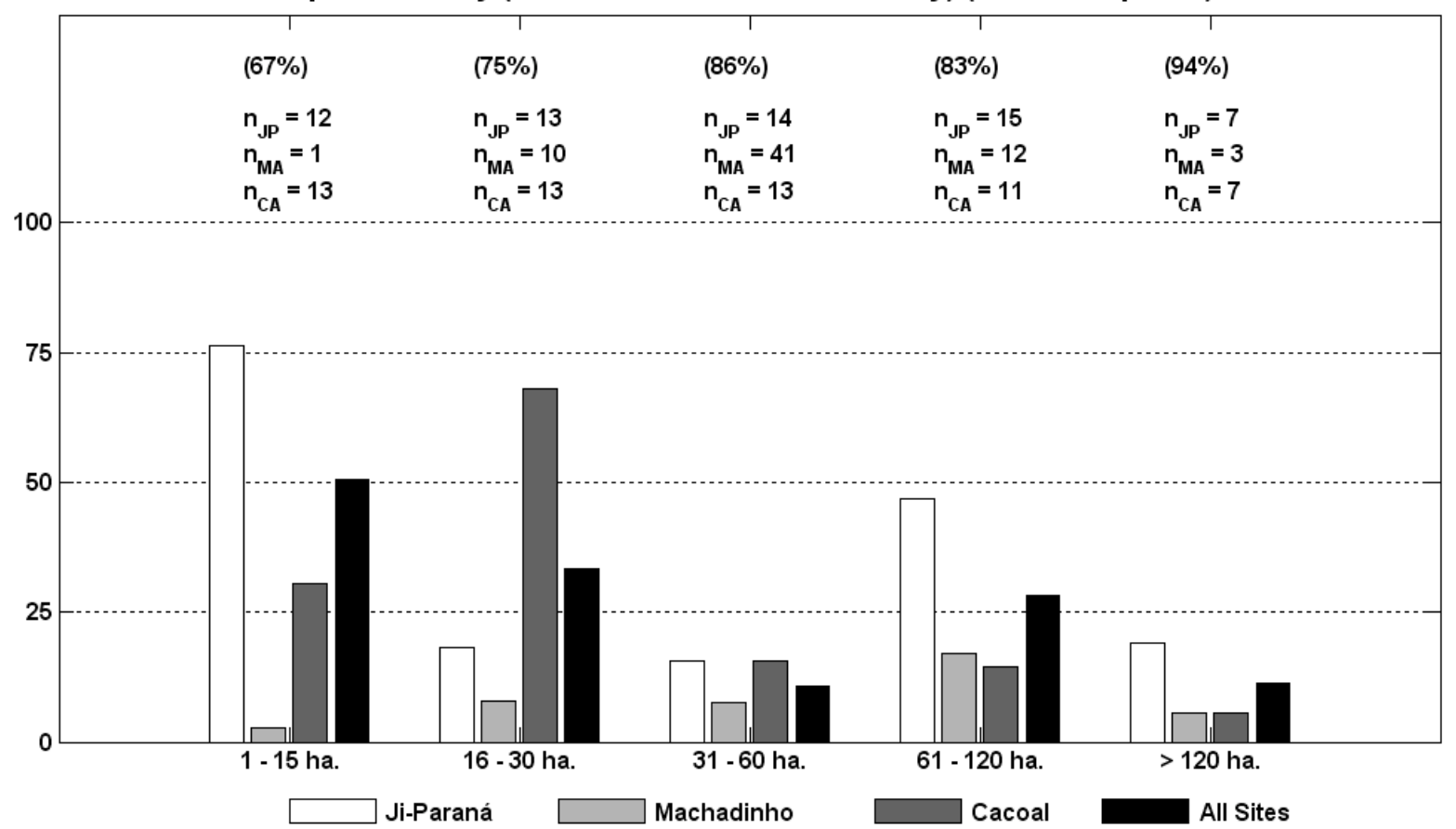

Figure A4.5: Input intensity (fertilizer and insecticide) per hectare of cropland. Percent refers to the percent of surveys in each size class used to generate bars; $\mathbf{n}_{\mathrm{JP}}, \mathbf{n}_{\mathrm{MA}}$, and $\mathbf{n}_{\mathrm{CA}}$ are the number of surveys used from each of Ji-Paraná, Machadinho, and Cacoal, respectively.

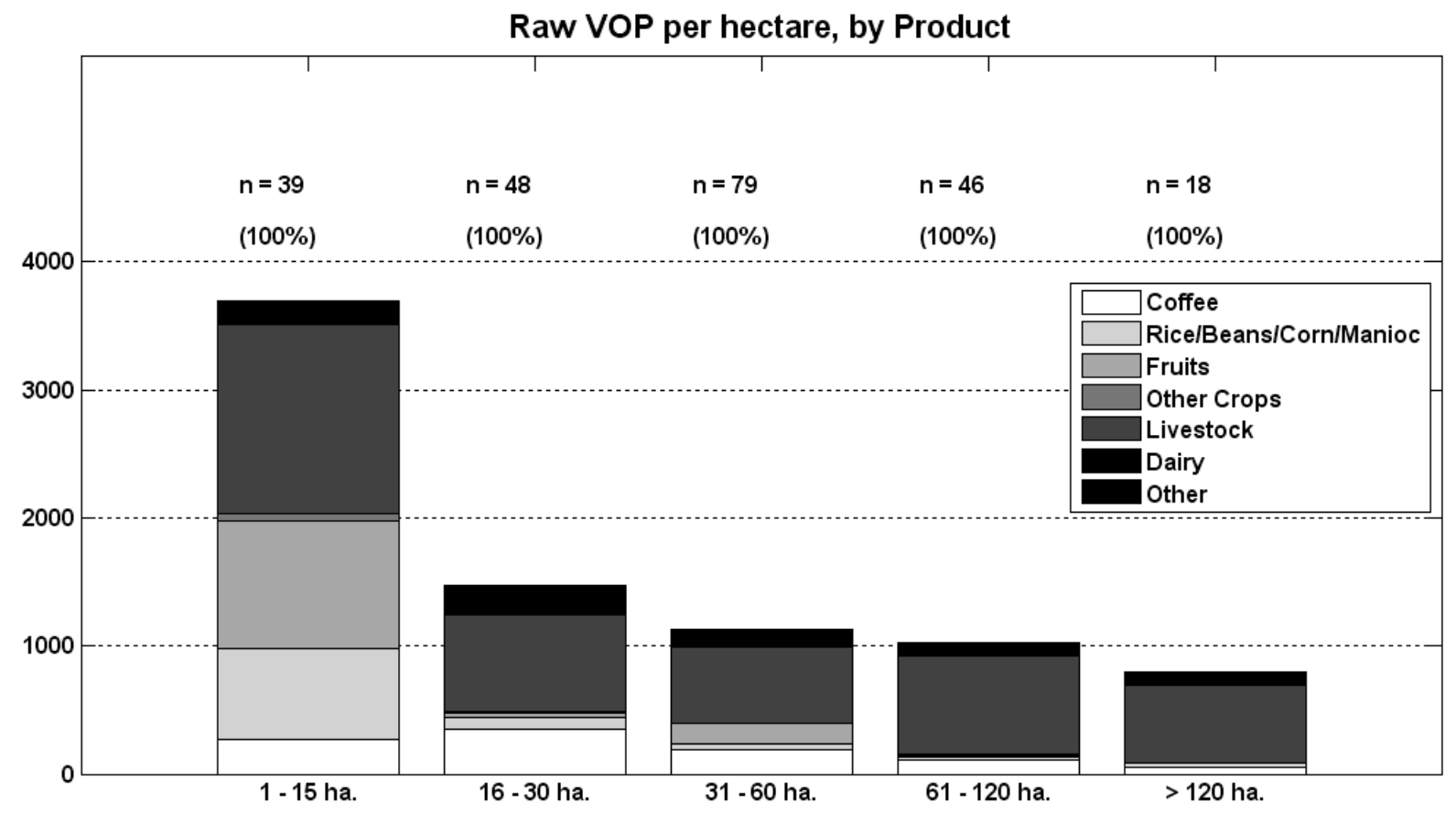

Figure A4.6: Raw VOP per hectare across entire sample, broken down by product. Percent refers to the percent of surveys in each size class used to generate bars; $n$ is the number of surveys used. 


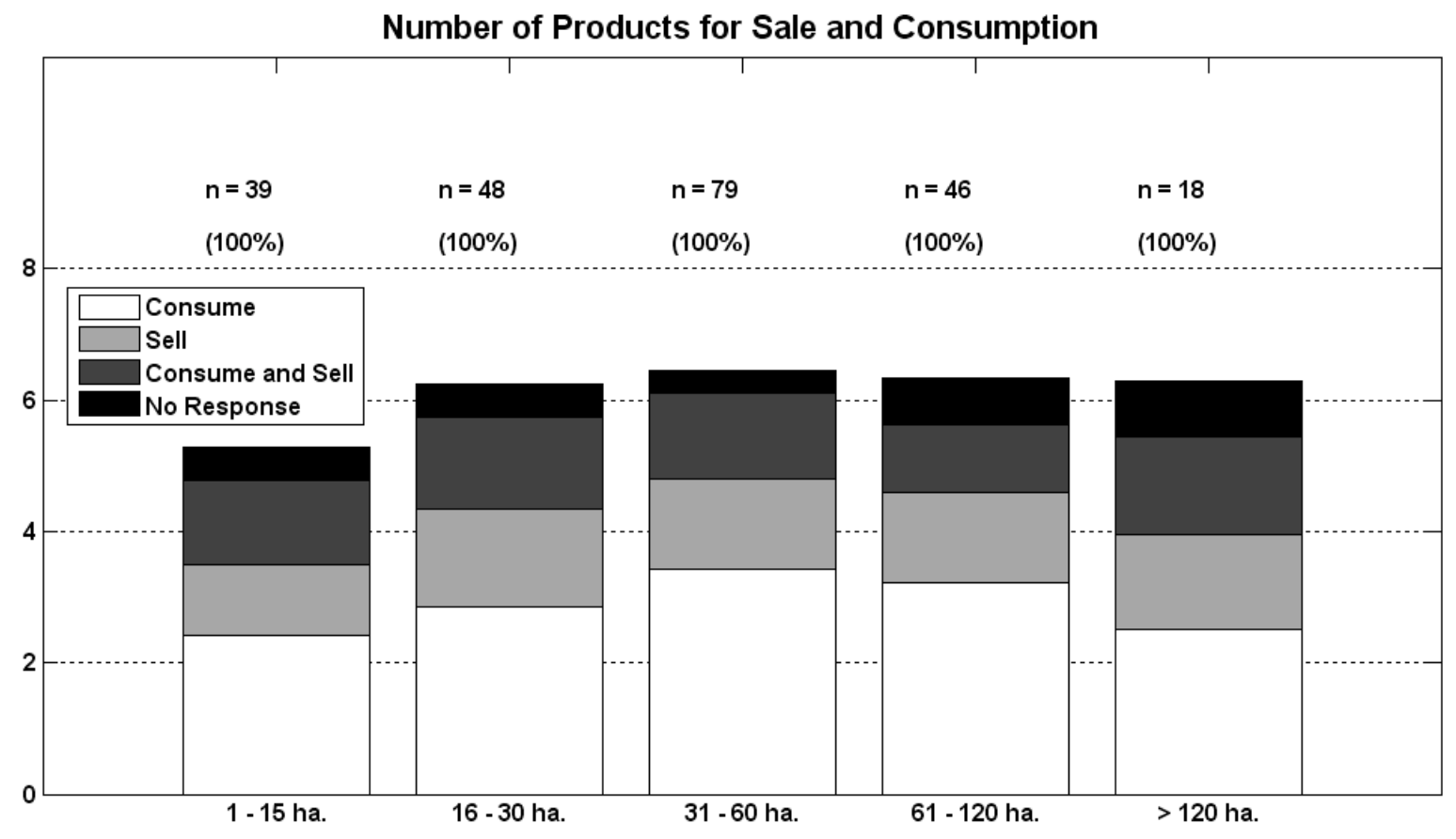

Figure A4.7: Number of unique products grown on farms for sale and/or consumption. Percent refers to the percent of surveys in each size class used to generate bars; $n$ is the number of surveys used.

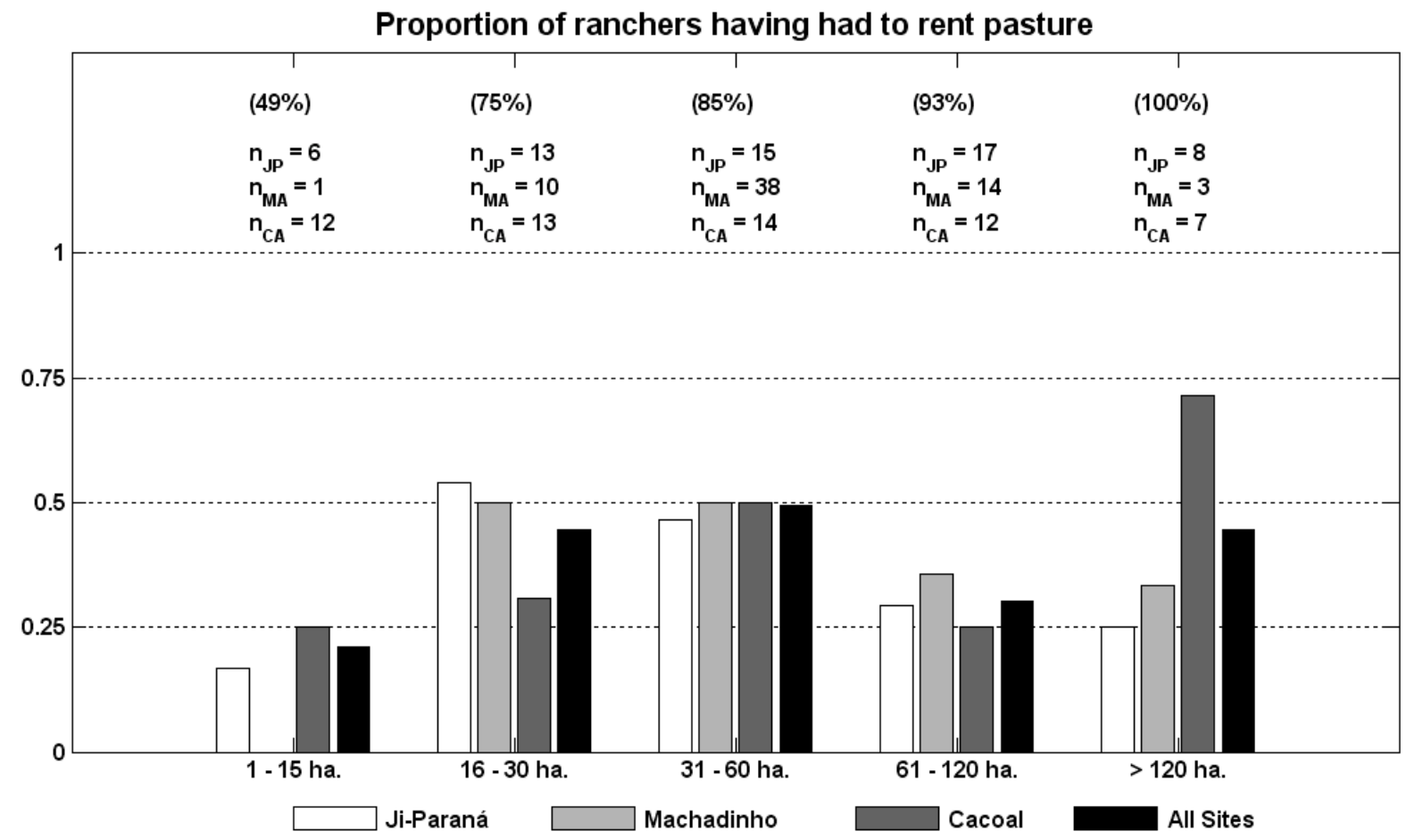

Figure A4.8: Proportion of ranchers having had to rent pasture. Percent refers to the percent of surveys in each size class used to generate bars; $\mathbf{n}_{\mathrm{JP}}, \mathbf{n}_{\mathrm{MA}}$, and $\mathbf{n}_{\mathrm{CA}}$ are the number of surveys used from each of JiParaná, Machadinho, and Cacoal, respectively. 